SB 269

.M3

Copy 1 


$$
\operatorname{Lrat} x+12,1
$$

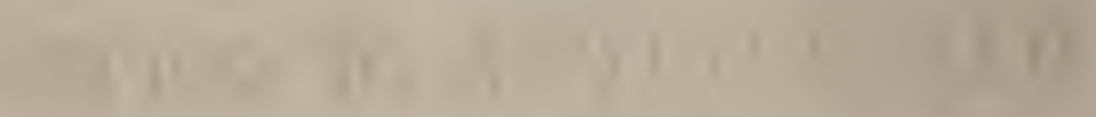

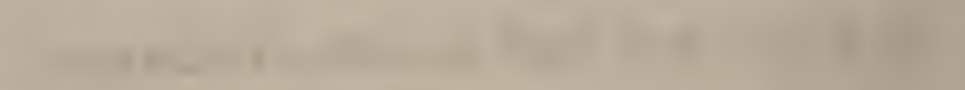

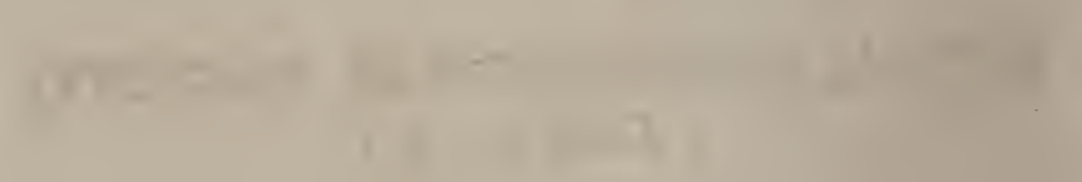

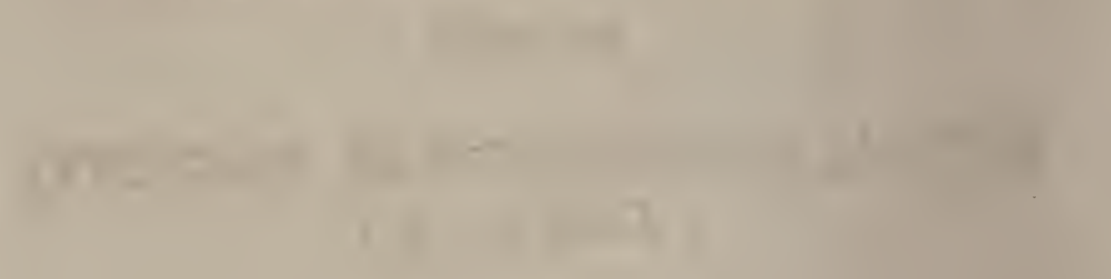$$
2
$$

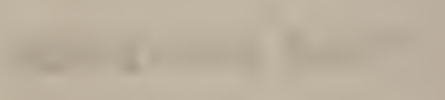

-

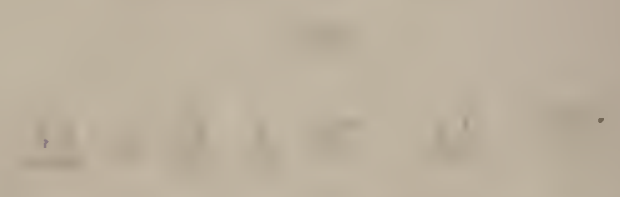

u.

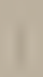

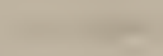

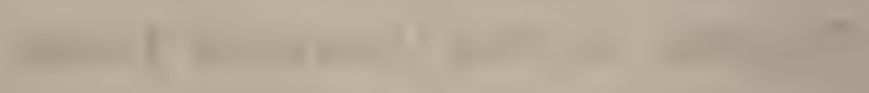

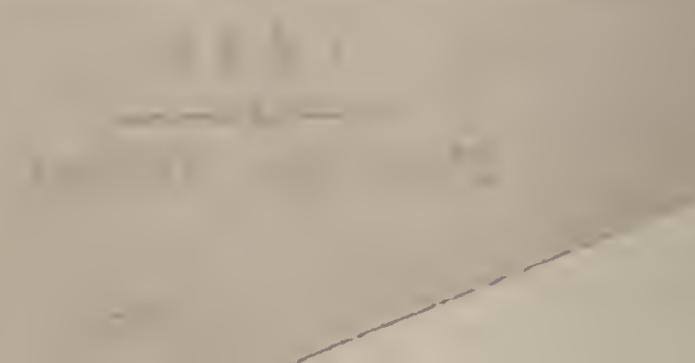


Gerbalo

Ati

ES S A Y

ON THE

CULTIVATION

AND

\section{MANUFACTURE OF COFFEE,}

POR WHICE THE PRIZE OFELRELD

BY

ROYAB ACRISURTURA SOEVTEV

(Jamaica, )

\section{VEAS ATARDED}

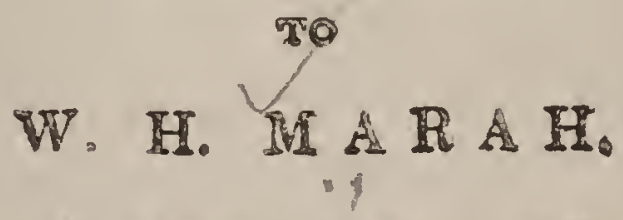

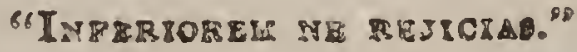

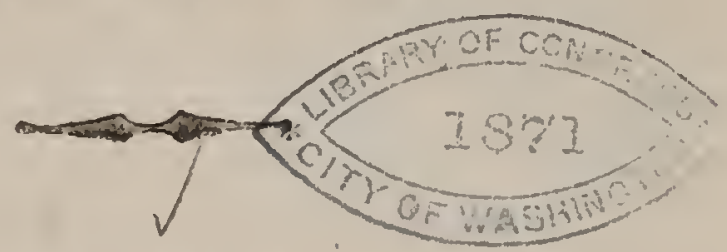

COLORBO:

Priftad at The OBSERVE Pregs,

$$
\frac{1849}{\text { Price One Shilling. }}
$$




$$
\begin{aligned}
& \text { SB269 } \\
& M 3
\end{aligned}
$$




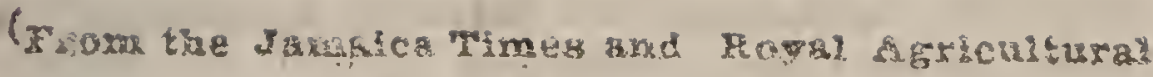
Society's Reportar.)

\section{啠 $\mathrm{A}$}

ON TIE:

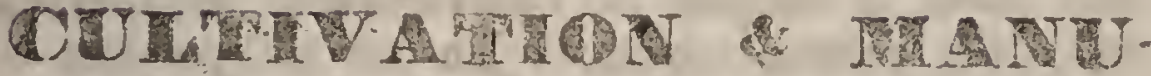
T. C For Which trie Prize, orfered hy tixe Royax AGRICUltupal SOCHETX, Fas MEEN AWARDEDTO W. H. MARAM.

"Inferiorem ne Rejicias."

THERE is no species of cultivation within the tropice, which opens to the mind of man, a more pleasing prospect and more agreeable work. for its contemplative powers, than that inciden. tal to the Coffee Tree.- From the geriod, at which the plant is first committed to the soil, till the trea has anived at maturity, the various chano ges which nature uncergoes, afford much for our armiration; but the time when the latter is most heightened, and wonder even ensues, is at the application of science and skill, by means of the pruning lnite, when nature assumes her heautiful dank green foliage, and the branches appear neatly eranged in their due order. I small slarub of a delicate and unpromising nature at furst, has now grown to : sturdy tree, which is ready to show its gratitude for the care besiomed on it in its tender years, by yielding ite increase ore andred foll bu 
to the shame of those who neglect it, bo it said, thes the tree, when established, is of an unusally hardy nature, snd nothing but the most culpable carelessness or palpable ignorance, is sufficient to injure or destroy it.

The due cultivation of the Coffee tree, so as to obtain from it yearly certain quantity of fruit, without distressing the parent too much, has been a subject of immeasurable importance to those persons engaged in its study; but a considerable diversity of opinion has occurred as to the best means to be adopted to gain the desired object.-This being acknowledged, it cannot be wondered at, that I should approach the subject of the present Essay, with much diffidence, and with all due deference to the opinions of those who have preceded me, and with whom I may differ. I parpose therefore, to give the result of my own experience acquired from the management of Coffee properties for several years, during which time I applied myself strictly to arrive at the best mode of cultivating "ioffee fields, to insure a good annual return from them, and the most effectual manner of manufacturing the produce so obtained, with a view to the improvement of its quality, in order to attain profit and pleasure.

The Coffee Tree, according to Botanists, is thus described-"Coffea Arabica, or Jasminum Arabicum-a genus of the Pentandria order, belonging to the Monogynia class of plants, pur ranking in the natural zothod, under the order of Rubiace"

Upon the authority of Monsier Raynal, we are assured that the Coffee Tree came original. ly from Uoper Ethiopican whore it was know 
from time inmemorial, and where it is said to be still cultivated with success. M. Lapince de Mejieres states, that he found the plant in the Indies, and made frequent use of its fruit; which was rather larger than that which was produced in Arabia, at the commencement of the cultivation of this tree, towards the end of the 15th century.

We are indebted to the Orientals for ou knowledge of the use of Coffee-we are told that its qualities as a beverage were first discovered by the superior of a Monastery in Arsbia, who, wishing to keep his Monks awake to perform the duties of the choir, was induced to make them drink of the infusion, in observing the effects which it had on the goats.Some people pretend, that its use twok its riss from a Mollah, of the name of Chadeley, to divest himself of a drowsiness which enthralled him, and prevented his attending to his night devotions. Constantinople was the first place where public establishments were institused for the use of this beverage-but these became the haunts of the idle and disengaged, politicions, poets, and Mollahs; and the discussions which ensued at such frequent and promiscuous assernblies, became so alarming, that in the reign of Amurat the third, the Grovernment interfered to suppress them. Edicts to that effect were issued at several periods; but the custom of drinking Coffee had become too establish$e d$, to be thus eradicated. The influence of Religion was even resorted to, for the purpose of discouraging the use of this harmless and refreshing beverage. In the year 1423, (320

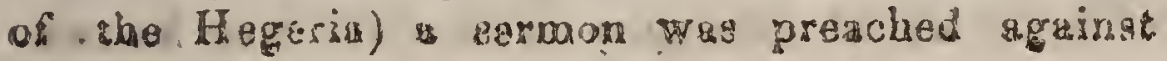


Ihe use, by one of the Hanometan Doctors which resulted in the peraccution of the Coffee drinkers. A meeting of the Divines was how. ever, called to decide on this momentous question, and thoy solemnly derlared that there was no criminality in drinking Coffee, from which period, the use of it has been allowed to sll trie Believers.

It was not ill the midila of the 13 th ctntury, that the use of unfieo was introduced into England. But ince tiat period, the tasto for it has gradually extencied, ard it bas row become a necessary of life.

The Dutch, the most enterprising commer. cial nation of the 1 th century, were the peo ple who firat brought the Cufree plant from tho Eust, and introduced it into Europe. They originally obtained the plant in Nocha, transferred it to Batavia, thence to Am-terdam, and at the commencement $\hat{i}$ the loth century, Houis 1th procured 2 plant from the latter place, which he transpianced in the Jardin des Plantes, whence it was distributed to all the French Isiands; bne it was frot sent to, and cultivated in the Irlisnd of Martinique.

The best Coffee still comeg from Mocha and Aden, hiliy ribtricts a in ibia Fellis, where there are stiti lavge plantations. In ilze cultivation, it has beeis asserted by travellers in that country, the Coffece trees are never topled and no attention is paid to praning, the planters contenting themselves with removing the dead or broken tranches and suckers which spring from the root. When the exposure i? too warm, they shade their trees by planirg their fields "vith a species of poplar: end when the berry is ripe, thay spread pieces or 
cloth belew each tree, in which the rips fruit is collected by shaking it. They do not pulp their Coffee, but having dried it on wots, they ranove the bardended envelope by the mill.

Accciding to Jamaica historians, the Coffeo plant was introduced into this Island sbout the year 1728, and the "erst plantation wân esta blisbed on Temple Hall Estate, in St. Andrew's. There aro many persons still alive here, who recollect then the whole Island did not pro. duce as nuch as ore of the large Coffee properties, in \& disvored district, during tio timo of slavery.

On the irst establishment of Coffee plantis tions in whe Wast Indies, the trees were alo lowed to gruy up in their primitive state; - that is to sy', the plant was pus in, in thes usual menner, aud kept clear of weeds; but no means wor taken to iscertain whether science could re applied to its cultivation, 80 as to rendes the tree nore fruiful and profitable. It was, therefore, permitted to grow to the heigit of ten feet and uptrards, as far ts the riciness of the soil would exw tend it. Fields art yet to bo seen in many 'parte of St. Andrev's and St. George's where nature has taken bre own cousre, and where the trees grow, in suckers to nearly twelve feet. These suckers, in good seasons, bear prow digiously, and, after bey are relieved of their fruit, die away, and five place to a new vegeEation of the same descrition. Anong the Frenon refugees who came ove from Haiti to this Islund, at the time of the revolution in that ill-fated country, this ytem of cultivation preveded; but they mere iaduced to silez trat 
caurse of management, and to resort to the use of the pruning knife.

The topping of the tree also assists in the reaping of the fruit, for in order to obtin the ripe Coffee from these tall trees, the laborers have generally to use long crcoks, to bend down the branches, and thus tho latter, when heavily leden, are entirely detroyed, in the endeavour to pick off a fer ripe berries.

We have no historical data by whch to ascertain when the topping of the cofee tree was first instituted, or when the use of the pruning knife was applied. One circumstance however goes to prove that science has been brought to bear on the cultivation of the treo for upwards of half a. centry; for there are frelds now in existence; of that age, and which show the usual symptoms of having been topped and regularly prunel from their establishment.

The soil best adapted to the cultivation of the coffee tree is the "lorse gravelly or stoney," and the "chocolate,- -but the tree sustains life, and yields fruit, though not to a great extent, in other soils. The rich black mould is peculiarly favorable to the coffee tree, and will produre it, like other fruit trees, in perfection, ir a seasonable climate: but I have seen filds established on rich soils throw out an immense foliage; al. vays appearing green and beautiful, and yet producing no fruit. An nstance of this kind is to be found in a higl field in Saint $\mathrm{Da}$ vid's, called Windsor. A clayey soil harbors untop in wet wertber willst it becomes dry 
and sterilo at the opposite change, and stops vegetation in the tree. It is not unfrequently mixed with a straturn of marl, to which so soon as the roots of the tree arrive, decay ensues - the first indication of which is to be observed in the yellowness of the leaves, which soon become shrivelled, till at length all drop off, nature yields, and life becomes totally extinct. In my experience I have seen large patches of coffee die off after this manner -without any apparent possibility of accounting. for it, but on digging down to the lower roots, the marley stratum of which I have spoken, is to be found. A plan was resorted to by an experienced planter, to re-establish a field, which had thus died away; he caused a small quantity of whitelime to be thrown into the hole (which was always dug very large) intended to receive the young plant, together with a portion of the upper soil. The tree grew, and bore for a series of years; but again became the victim of the marl. It would, therefore appear that the warmth of the lime had been absorbed by the chilling dampness of the marly stratum, and that the latter availed itself of its power to communicate its deadly breath to the roots of the ree.

In virgin lands, after the usual preparation of felling and clearing away the wood, the Coffee plant is put in, in the following manner:the land is lined off into rows of from 6 to 7 feet square, as the richness of the soil and the prospects of climate may warrant. At each square, pegs are inserted in the first instance to denote the snot assigned for the reception of the plani, 
snd the persons eryaged in putting in the yourit aucker, follow on with a delve, and as the per is removed, a holo is mado about eightetn inches dee $\mathrm{l}$, into which the plant is inserted, and tho carts niled gontly about it, leaving from six to eight irches exposed above the 3urface of the earth. Formerly it was custoruary to raise nurseries from the sced, whence a regular supply of young plants could be obtained in the laying out of the new fields-but these have fallen into disuse, from the quantio ty of young irees which are to be found growing wild on thrown up lands or plantations, the growth of berries which are taten from cultivated fields by the birds and rats. Fhe quantity of fruit which is annually lost to properties by sundry ciuses, such as careless reaping, birts, rats, \&.c. torm of themselves nurseries under the "rees, and these furnish plants-but on all wellzuanaged properties, these latter nurseries should be eradicated, as they terd much to impoverish the sois, and to rob the tree of that aliment which is escritielly necessary to its preservation and longevity。

The suckers are ồnow, trimmed of their roots, and cut about two feet long. Good stcut stumps are genernlly prefered, as they vegetate with greater strength. Plantations were formerly establishod from the seed in the first instance-but I have not known within the last fifteon years, snch a course to have been pursued.

It was chstomury to plant corn, peas, and provisions through all young ficlis, till the trees were about three years old, but the great alteration which has taken place in plantation ceroxory sixce the exancipation, has beea nuch 
is in abolish this practice. I do not think thas either corm or peas do any injury to a young feld-but provisions decidedly tend to exhaust the soil and keep back the young plant.

Young tields reruire inmense care, in consequence ot the ranknes of the weods which some up in all new soils. It therefore becomes necessary to clean then at least four times per annum; and at ecch cltaning, it is requisite to supply all the plants which have not raken, in order to insure a perfect and regular field. A sinall eye is the first sympton of vegetation which attrets the observation, then a bud, a conple of lerves, and joirts cond leaves follow in the cotrog of rature's opiertions

The young tree shoch out its lateral branches at each joint, which follow in regular succession, iill the tree arrives at the height of four fees six inches. It is at this perior when science is first called into action, by the topping of the tree, which is ierformed by cutting off the six inches with a knife, so as to form a tree of "four feet. This operation has a wonderful effect on vegctation, the brancises in their turn, begin to throw oni buds, which in time become the limbs termed collaterals; and, in the course of eighteen months, the tree will have arrived at its full bearing point, furming a spectacle of 'amazing beauty and orise', bud presenting a remarkahle pea-grces isue.

In late years, since virgin landis, adapted to the growth of the Coflee Tree, have become so distant from the works, trials have beeu znade on plantations, to establish fields on throw: up bands and olk negro grounds.

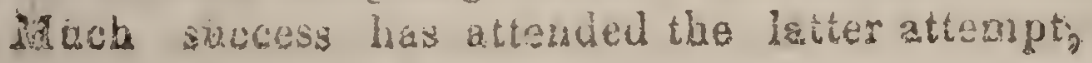




\section{( 12 )}

Wut the trees do not grow to within one hall the size of those planted on new soils. Lands situate contiguous to the works might be astablished in Coffee, by the aid of manure, however poor the soil may be, but immense care and attention will be required to effert it.

Trees, after being topped throw up suckers from each joint, but more especially at the head. 'These must be removed at each cleaning as they grow rank, and rob the tree of its support. The wood of a Coffee tree is of a greenish color, and rather soft, when young; but as it ripens, it assumes a brownish and hardy appearance, In topping young fields this appearance must be strictly attended to, and the trees should not be topped till the wood has ripened at the cutting point. I have known young fields, almost ruined, by being topped too early, before the wood had sufficiently ripened. As young trees commence being planted, and as they generally bear heavy at the time of topping, it stands to reason, that unless the mother stem be sufficiently ripe to bear the weight of the branches loaded with fruit, the unripe portion will wear away, and thus the tree and fruit will be destroyed.

The climate as well a.s the seasons vary so materially in this island, that the growth of the troe, as well as it cultivation, nust differ according to its peculiar locality. In the parishes of St. David, Port-Royal, and St. Andrew, where the Coffee tree flourishes best, and from whence the best quality of the article is produced, an entirely different system of management is pursued to that which prevails in Manchester, St. Elizabeth's and St: Thomas in the Vale,...ia 
the former district, the tree does not come into full bearing, before it is seven years old, whilst in the latter, this takes place in one half the time; and the longevity of the tree bears a more retrarkable difference; in the one, fields are to be seen now fin cultivation upwards of lalf a century old, whilst in the other fifteen years may be taken as the mean age. Soil does not of itself create this strange difference, as the same indications of favorable moulds are to be seen in each district, but it may the rather be attributed to the difference of climate. In the upper districts, where Coffe plantations have been established below the range of the Blue Mountains, the temperature, though cold and bleak, is dry and healthy, whilst in St. Thomas in the Vale, where the lands lay considerably lower, the atmosphere is warm, though damp, and visited with a continuous supply of rains and fogs.

The most difficult and yet highly important portion of plantation management, consists in the due attention which is required to keep the fields regularly and properly pruned. This is a subject upon which planters are seldom found to agree-each one has his own peculiar system of pruning: some recommend heavy custings, others slight pruning, and not a few no pruning at all. Arnid such a jargon of opposite opinions, we must adopt the motto-" in medio tutissimus." In my opinion, one of the many evils which has been inflicted on this country, has resulted from the injudicious and indiscreet morie of management which was pursued upon plantations. Whilst large tracts of woodland were at command little or no attention wa paid to the kegvirge in cultivation of ald stan 
blished fielde; these were allowed in run into waste, to give place to the large returns which were anticipated from a new and rich soil. Indeed I may safely say on this point, that the usual indication of vamaica characteristics was palpubly erident, viz., to live for one's self, and not to think of posterity. Acting under this spirit, plantations were run over, and considered worn out in the course of a few years, whilst, with a proper degree of care and precaution, they might hav retaines their names, and kept up their crops for a serios of years. The pruning system then adopted, tended much to accelorate the ruin of propertios. As labor was abundanto it was customary to commence pruning at an eurly season, befure the crop was taken off, and the destruction of a few tierces of produce, at the fag and of the crop, was considered of no consecuence. By dint of hean y and severe cuttings, the trees were forced to the utmost of which nature pres susceptible, into copious vegetation. This exuberance of young wood, the tres could not sustain to perfection, and the rajor portion was therefure consigned, in turn, to the finte of being torn away by the openers, to perish to secure tome ventio Intion for the tree. Thas was that undone, which nature had been forced to perfurm. These heartless bleedings were repeated year after year till nature was exhausted, and the tree would yield up the ghost. This system of management same under my own observation, which has in. duced me to allude so pointedly to it-more so as it was set up as the ue plus ultre of planter ship by those who had numbered their aighteen and wwenty years experience in plentation ratuagemont. 
When filois have been neglected for years becomes absolutely necessary to resor to severe pruning to re-orgnnize the tres; for it stands to reasor, that constant vegetation irrecularly kepu up, must choke the trees: and prevent ventilittion: while the decrying and neless branches would still spring, and diaw sustenance from the good and regular. And as the tree continues to bear yearly howere little, it must becone one mass of vegetation and irregularity Such being the case, it is inmossible that the bearing wood can attain perifucion; but be the rather stinted in is growth, sind become useless and unprofitable.

There can be no specifc rnles laid down for the guidance of the uninitiated in the art of pruning. General rules might be spoken of but they are so liable to be intertered with in their application, by constant changes in the climate and the seasons, 83 to render their intent unavailable, In my opinion, the best mode of management is discarnible in hin, who takes alvantage of the appearance of nature, by an application of his skill, when that is required to assist the tree in nature's operation.

'The tree, 8.3 I have before observed, throws out lateral branches in the first stage of its growth. 'Thesa are called primaries, and should they be sut ofi; or broken from the stem by accident, their place can nevar be supplied by a growth of the same kind. Suckers and "gormandisers," of which I shall hereatter speak, take their place. The coliaterals which strike owt in at littral direction trom the primailes, andurenenty become the legitimate victim of the pruring knife, ufter their beardig. But in often hampens. 
that as nature promiscuously sipplies this vegetation, a larger corp of collaterals might be generated, and draw more aliment from the tree, than it is able to support, and bring the fruit to perfection, so it becomes necessary to resort to science, and to select that portion of the wood which is healthy, strong, and regula:" and take out the puny irrogular, and super fluous.

All shrub trees require a certain amount of respiration, to conduce to their health and vigor. With the coffee tree, it is indispensable to its healih and life, that a constant and regular circulation of air should be transmitted through the body, and to this view it is necessary that the heart of the tree should be kept entirely free from vegetalion. After a severe pruning, the vegetation is rank, and studded. The prudent planter watches his opportunity, and so soon as he perceives the young wood of sufficient growth, to admit of in exercise of judgment in its selection, he directs the opening to be performed. The heads of the trees are first to be stripped of all $\mathrm{r} \theta$. getation, so as to form a clear area of at lesst siss inches from the original stem, afterwards all that which runs transversely; and as the opener proceeds, he takes out every thing which appears "spindly" and stunted leaving the rich lealthy "black" wood to produce the crop.

When fields are kept in "good order," by light annual prunings, there are always two growths of wood to be seen coming on-the first in advance and ripe for the crop, and the second shooting out, to ripon for the ensuing year. My opm princioke bas bsen to follow this course, 8 \% 


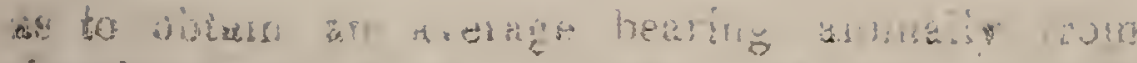

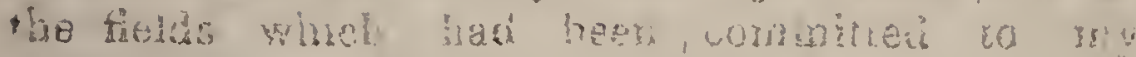
cure and mansgement

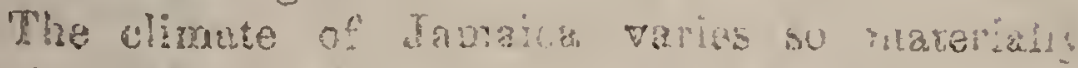
in itg diffuent tocolites, risat no disturt periou can be sirted as the rost finorable for pruning. In those altituder, whele tho coffee tres vegretate alnost all the ycar, rou?t, I Inve known pruning to be performed auring the rinnle period. It stands, murer, to reason, tiset there are certain periods ne the year, when the sap lieg dormant in the tree, and not the shightest spring is perceptible. If the objut he to obtain a copious ant healthy sujply of young wood, I do not think that season suitable to the purposemas if bave observed fields prorent in November and Decentier, venain in a dormant state, and not throw out a single partice of young wood, till the spring of the ensulng year. The moning of May, Jur, Jily and 4 gust, have sorned the season in which $l$ biserved isfe pruming to act beneficaliy on the Coffee trre, in the upper districts wisere I was principally located. But is has oltertines bay. pened that in a late crop, the fruit is not taker. of by August, consequonty the pruning bact to he delayed to the months of September and October, atter which period $T$ consider the curting a field for uroot pertectly vairelss, and a mers waste of labor and monoy.

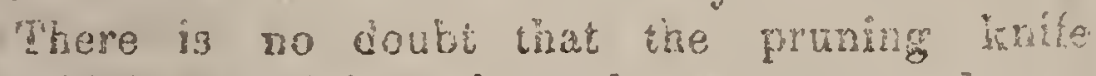
ohnuld bo administered to the tree as eariy as

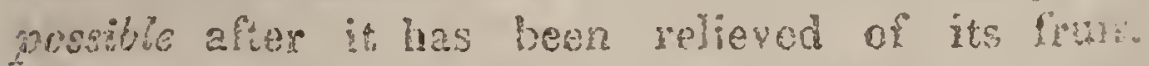
it has occurred to nse, however, that this rewReive showh to coningent on the scasous, but

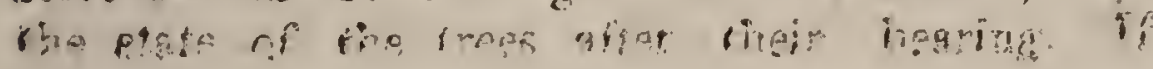


the weather has been peculiarly seasonable with a heavy crop, vegetation will have comanced before the fruit is entirely renped, or more properly speaking; about the end of the crop. In this case no harm can result frovs an immediate application of the pruning buife; the same course would also bo equally justifiable, when the fields have given but an indifferent return, and are in no wise distressed. Taking an opposite view of the case, however, the subject appears io me to wear a totally different aspect. If the field has borno heavily, and appears distressed, presenting a mass of "white" and almost lifeIAss wood; I should think an immediate pruning Inighly injurious, for it stands to reason that it would be compulsory in the praner to cutaway all the old wood, according to the strict rules of pruming, and the tree would as a consequenco be left totally bare, and coula not possibly give uny yeturn for two years at least. Now, had a swall respite been affurded the field, till nature had sornewhat revived and vegetation ensued, the pruner wond be enablea to sce what should really be taken out-some portion of the old wood would thus be saved, which would give t. small return for the ensuing crop. A circumstance of this nature catne under my own personal observation in the year 1840 , when I was zesiding on a large Coffece property, the fithis of wich were silmater hirgh, just butow the Blue

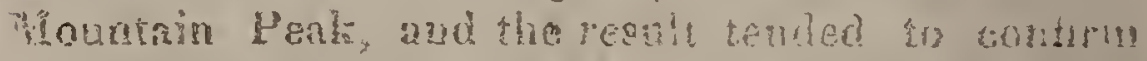

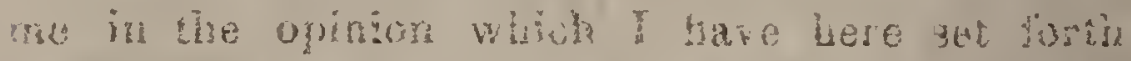
in thet year, there was an axperting drought throughout the count:y in whit te dise dised ot

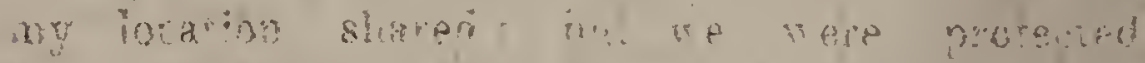

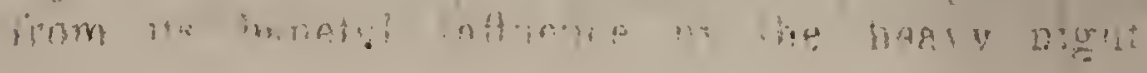




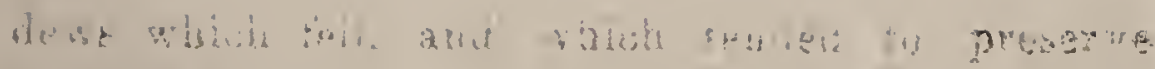
* bite moistirt. the weather durng tis? me. roding vear vas also rathe d!y in that districh. and ax subh wa macher faromable to so wot ami cold a clinate. the crops of jofo were tharn. ince bather large, dowbling nearly those ot sereral vaats' preceding. 'The property which I malacen made its fit tierees. my neighbon: whe aljining property ande the ague erop mol indeed the whole district mach yeturn proporionato to the wapabilities at the severut properifur. As the weather had boen so exregedingly dre, and the tields appeared much distresserl, aftar the crop had been taken off. fand which by the way lasiat till the lnt of Angusi) ny first ottention was directed to thom cleaning of the ticlus, which are generally maker wirl meeds at that season than at any period ut the yoar. This task / commenced in anrs.

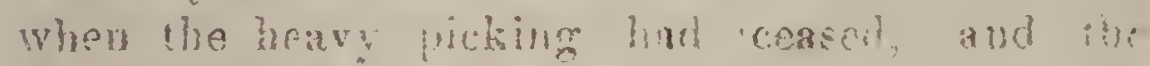
labor could be thus sparet, and was cornglewel enrly in Argust, Wo wore favoled with a tew

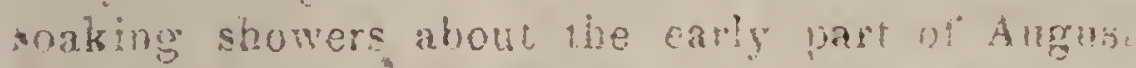
and tile trees began to revive. So soon as olserved this rhange $I$ sent in the priners to crmmence operations, and succeptied in puttinn the entire fichds in good order by the lst ut 1)icber. In the month of Seprember we sh.

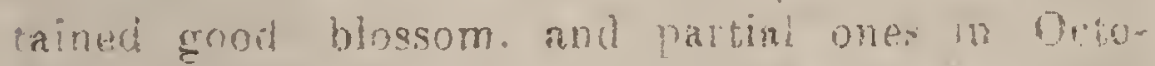

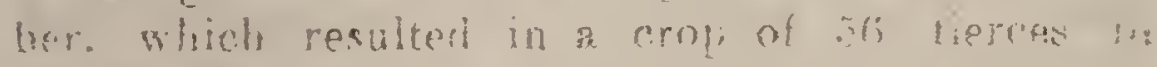

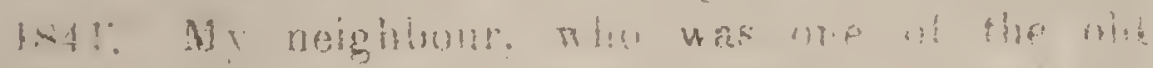

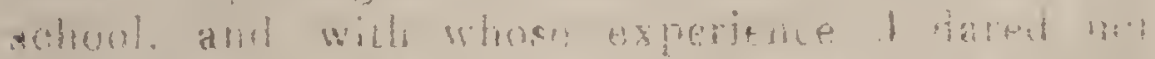

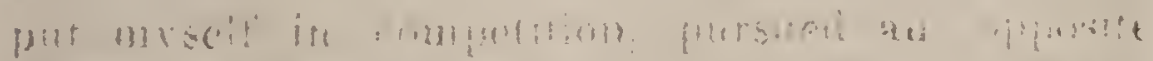

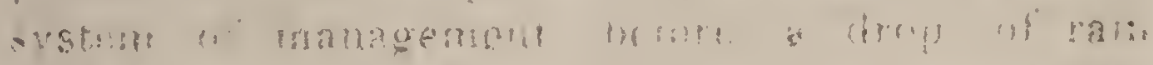
lar ali

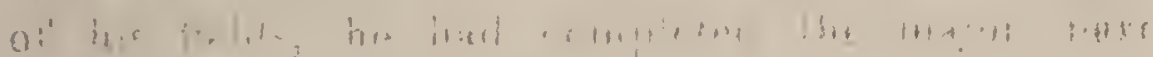


in: it

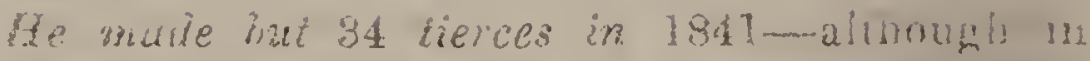
the same locality with equal advantages. I may also ald, in furber proct of the efincacy of the syetcin to which I bal given the preferetcet. fuat an overseer in the sarne district pursueil my mode coeval with myself; and that the sarue resulis atreuded his ensuing crop.

My atcrution was at the time pointedly drawn :o this extraordinary difitence of opinion be. ween wy next door noighbour and myseli: and 1 was the more deterinined to watch the rtsults. My neighbour argued that he always expected to make a short crop after a heavy one, wha it was therefore necessary to spcrifice sume wood by pruning early, in order to force the trees fo throw out young wond, to produces dintlup harge crop in 1842. The seasons huteres varied, and my neighbour's expectations were loomed to disapmointment: for in llat year In lid not even realize his 1841 crop.

lhos it appears perfecly convinoing to ne that his sacrifice of which I have heard planatry surak as highly justifiable, in order to pusle fur a large crop-is palpably inexperlient und thgranly injurious. There can be no certair calculations mado on the seasons. The trees yisght be in a stafe of perfection as to orderm. the indications equally as comrlusive on the mind as to the promise for the next urup, when a sucter biagt might kestroy all our mnticha-

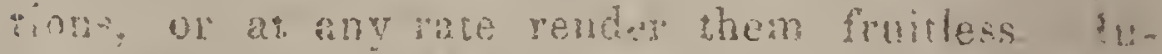

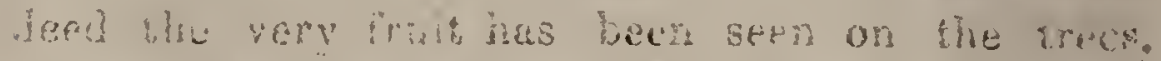
sul heary winer has odten loomed it all. wo arighi 


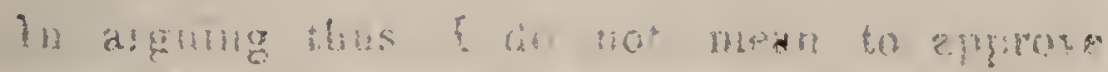

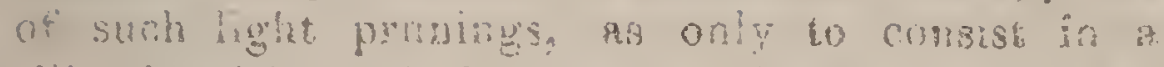
siliy hasuling of the tree, while a grat dealot wood is left betind. which must drow snctios, which neither adorns tis trese nor is profirable to man. There must be a rucdium in all things and that median is peculiorly required to bis observed in pruning. Woor, when ouce it be?gins to assurne a jellow tinge, givas fovdent prouf ot ill-health-it should linefefore ke takx: rut, together wib all long brauches, will m

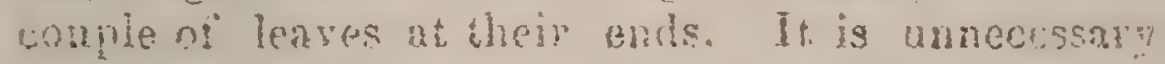
its an essay of this nature to enter ton muchint? minutia, aut enmurate the soveral appenr. ances of the branches, which it is recessary te cut ont, of of the wood, which tho puriser is balled mpon to victimize when lie meets with

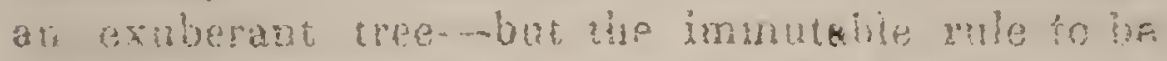

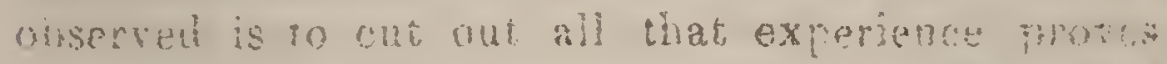

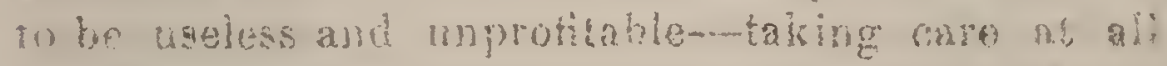

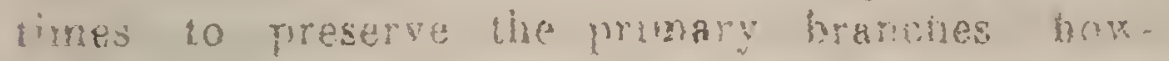
ever deicoted thay may appeisl: moless thes be tritally read uns dr:

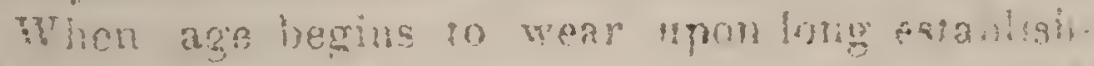

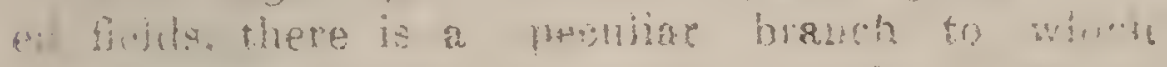

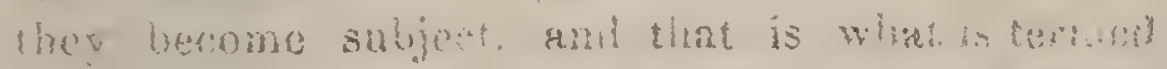

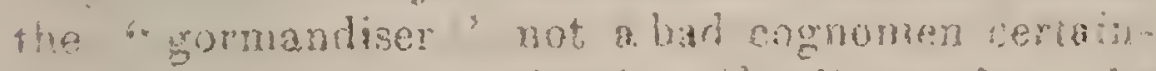
1:- for it sucks voraciously atl aimumbon th trese. It is of the sume speutes as suchers: mith

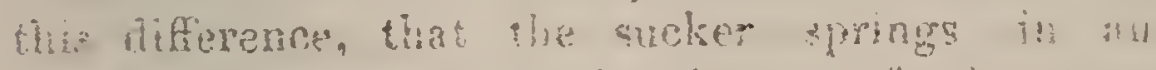
mprigit direction from the jornts of the trut: whilst the gomandiser otocte cut homzontaiy. 'frees sufter mush. and soon waste awny; where

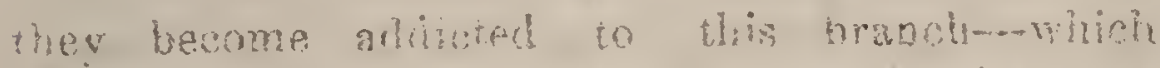

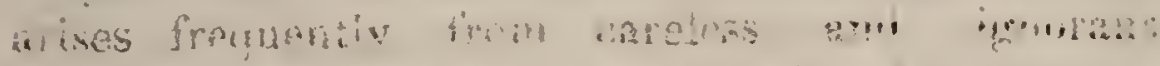

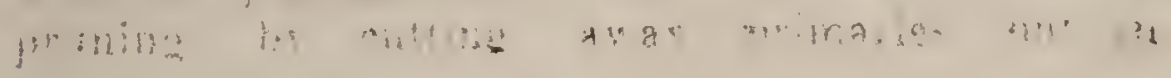




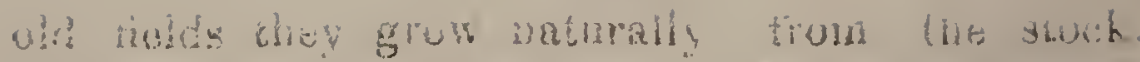

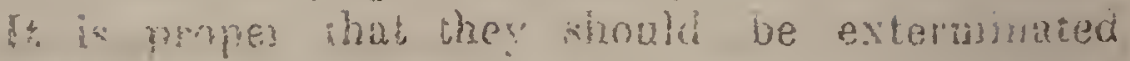

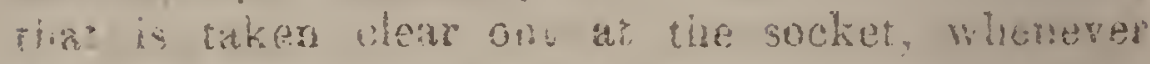

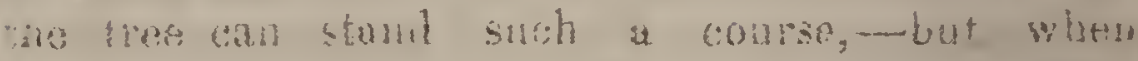

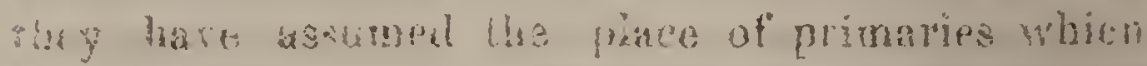

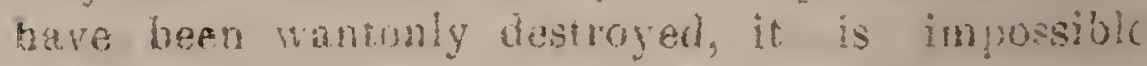
ta chango thrig orles. tur su snon as one is

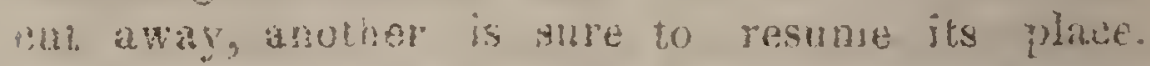
s: likat case, it will be as well to allow lhan so vemnin and bear, taking then out atier

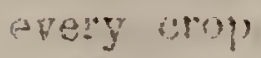

Pruning is as escential o the cultivation and rasovation of the loffet tree, as menlicine is in the resturation of ihe sick man's health. It hus Ilyereforey sonnewhat suprisfi me to hear ben whom tis word have thought experiune Hud inade safo in naturi's laws, condenr pruwing as unkrlled for and injurious to the Cottee tree. Fields bave been kanwil to bear fiol d. Succession of years, after an enire ubsence. of the pruning hnife; but it nas been as well observed tha the irefis sufier nost materially alter that priod and will not produce aiy tivits fo: another tern of years. MI". Starmy The former proprietor of Mt. Ilolstein in St ceorge's, tried this plan-me had an overseril who was a goorl pruner, and kept the propariy in sood pruning order, but who left in 1830

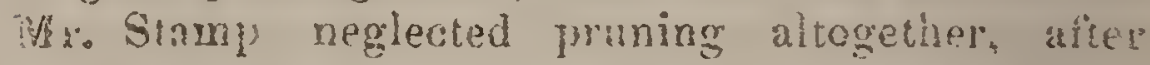
It took linon himself the actise managemant-?: fisirs bore heavily for four vears after, inls;

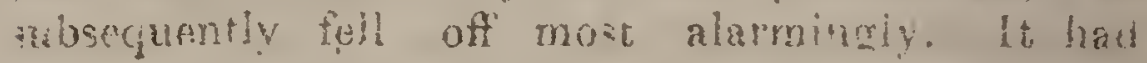
meviously aremged its lun tiemese int lell oft (i) $20 .-2$

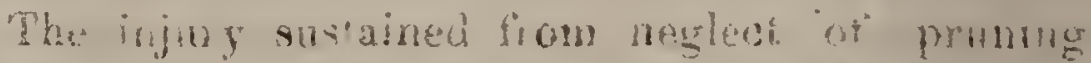

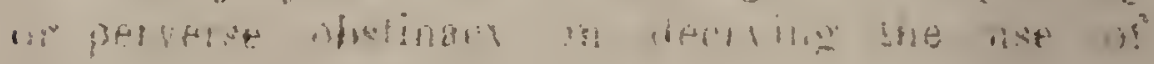




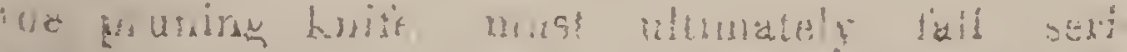
susly on the moprialors at cuifee properties, to: the outlay loguisite to jut a reglected feld in good order, is equal to three times that which would have suffices for an ordinary pruning, besicies the total loss of two or may be thres years' crops. A tree conce matted up, and allowed to pass over a winter, is sure to lose a portion of its primary bunches, from the want; uf a circulation of air. As these cannot be seplaced, the tree forms a jutlect umbrella, and fruit can only be obianed from the top branches, afier the tree has undergone a thorough pruning; and almost a rearganisation of wod.

In iowlend divtricts, and more especially ir: Manchesier, St. Wlizabetbs, and Git. 'flomas is the Vale, very litte pruning is required, und the same is auplicable to felds established on light and sandy soils. In these disirictsy the breaking off the dry woon, and nipping off $\%$ fow switches sunstitute the whole ari-mbut in the isigh mountuins, where the rees grow to an exuberance, to cover an area of form thirty to fitty feet, the art of pruning them is rejlete with science, and forms a most essential featureof theil culivation.

Gentlemen who lave been accustomed to the management of properties in those districts, where the erees are small, become entirely bewilderedy when they behold the magnifirent foliage, which the folds exhibit in the bigh mouniains. Ir this manner great e!rors accrus, and much injury is sustained, by encluaroring to assimilate the extent of pmming rosulisite in the one dis-

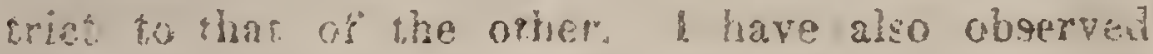

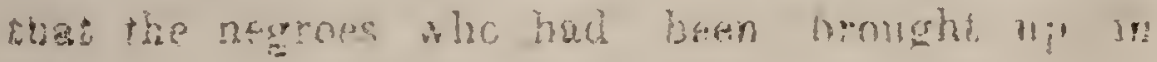




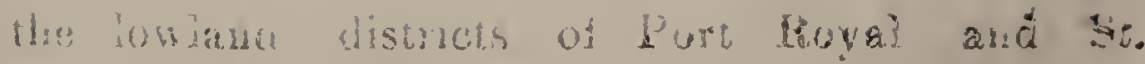
Hndews. and who sough amployment in tas mppez part of sain David's, after the enanciFaton, "vere yuch astonished, and sit themo salves at a loss in the use of the knife on the tields to which they had transferred their labor, and they theretore made but indiferent pruners. A. sever pruming in st. Thomas in the Vale woidd be attendul with injurious results. Though that parish is exceelingly damp, ombedcled in togs, and viaitcd with continual rains, still it is highly remarkable that a moderate St. David's zouning would entrely ruin the field to vilicit 7he system might be applied. While I was in rat parish my ationtion was directed to anextansive feld, which had been entirely ruined, and ss klow throva 140 , by this injudicions course ot namagement.

a queation was mit to mo a fen weeks ago by a gentieman who held the attornoyship of an extonsive Colse propory bighiy siquated, ... tie desired so know whether it would not bt arvisable to allow riold, which ma exposed

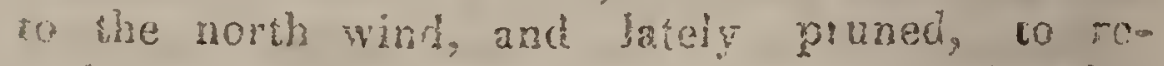
sngin with its motted young wood till allow the spring of next, yea!. in order to protect is from serious injury at that pariol whon the noth winds are so prexilent. My ariswer then Just brings me to a consideration of what is

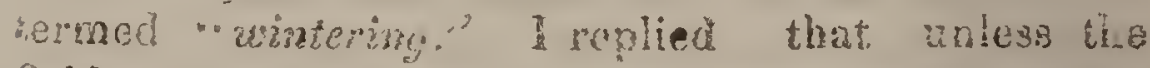
fleid was well opened, so as to preserve a ripe circulation of air, aud permic tace reys of the \$4lag to strixic into the huret of the trees, to weato some wamth, the fiold mould most ses.

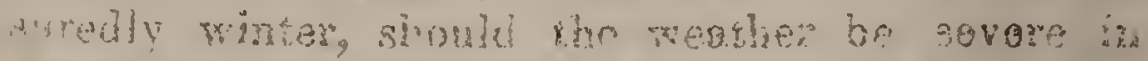

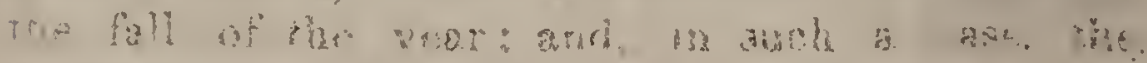

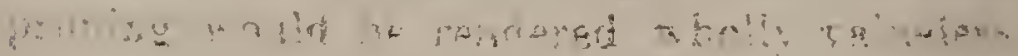




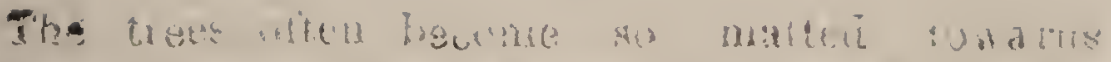
the heari, flom an excess of vegecation alber livuning, as to becoune entrely impervious to the rays of the sun, forming perfect umbrellas, undor which a person might seek sheter from a shower of min. It therefore must be obvious that their state could not resist the cousequencrs which must ensue from the heavy rains that fill usually in Dotober and November. They would bather habor the wet, and accelerate their own destruction. This event is brongis, about in a most remakable mamer, the leaves contract and drop off, the bruches being previously chilled, and in many cases tive laster die off; but shoukl this not ensue, so fal as the ensuing crop is concemed, the rwoot becomes totally unfit tor bearing, A new vegetation will cone on in the spring; but from the bleaknuss of the chinate, the wool which thus geaerats wili not ripen in time for that crop, but may be avainbie in the onsuing your, if proner care be uscd that repetition of the last yeal"s prockedings does not lake place.

Haviner sald thus much of probing, it nith be necesury to make a fery observations on artother mortion of cultivalion-whe weeding. I have griven precelunce to a consuleration of the? ait of pruning, because 1 conceive that lat of cuitivation, of momoms importance. Whe due clenting of Cotize folds is equally reguisie to their proper culture; but this jorms a ure piece of physical labour. regaring veibler skill nor ingenuity in its excrcise. The Airinn, the

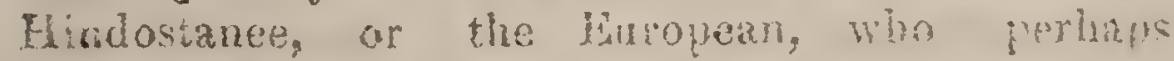

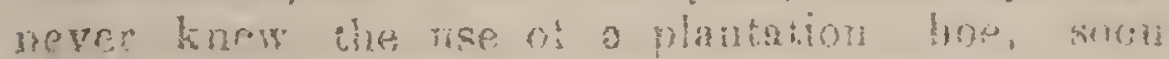

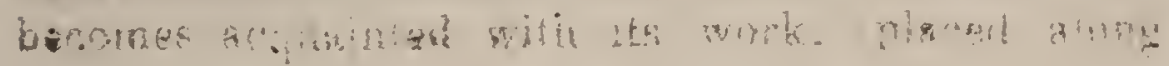




\section{$26)$}

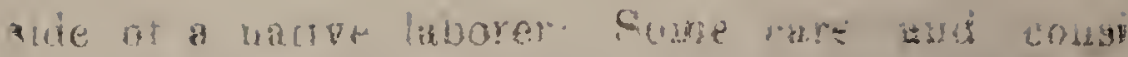
daralion at:e linwerer. due to this portion ofnasaugenent by the intividual who diroets its porformance. Foctulisher fields in ty cimates, do not weed nore than two weedings a yearbefore and atter erop; but in wei climate, three or four are requisite. In my opinion, the systum of scraping away at fichls so repeatedly - -parlicularly on hill side lands, inas tended mnch to impoverish them, and wash away the roper soil; and the exposure of the latter to the. vertical rays of the sun, immediately after a cleauing, is apt to render the land stiff, and more or less, a portion of its nutritive powers, is this withdrawn. The weeds, which are taken sut. by the hoe. form an excellent manurethey should therefore be heaped up beside the tree, to admit of decomposilion, and at the next clpaning, the mould thus obtained, carefully appliced to the roots of the tree. I knew a propurty, where it had been customary for years to heap up the weeds in the ceutre of the roads, till a rggular moind was established, and the trees appeared as if planted in trenches. An observing planter, who subsfuently succeeded to the management of the property, enquired the cause of this strange appearance on the surface of the land, and un being informed of the cirm "umstances attending it, directed the mould to be dug down, and tho roots of the trees wo'? mambled up with the loose earth. This was recomlingly done, and a most wonderful result was the comseguence. The freld soon presented a blonming ispers, in the richness of a luxuriant Whinge. arst is noture was so far ascisted in her whlthings wo wa- the hountifn? ir ber grifts-ide 


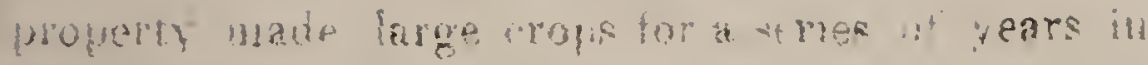

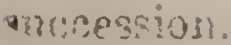

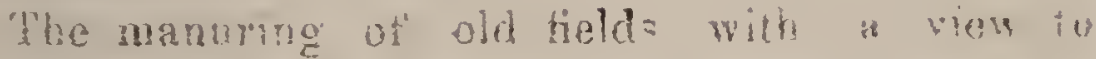

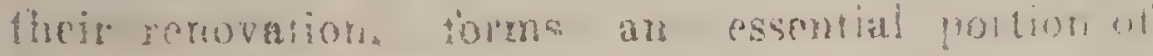

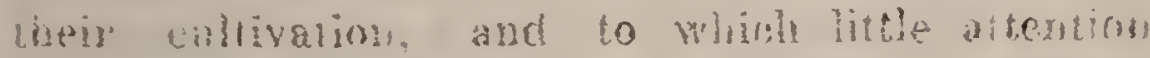
was formerly bestowed. As I infore biservel

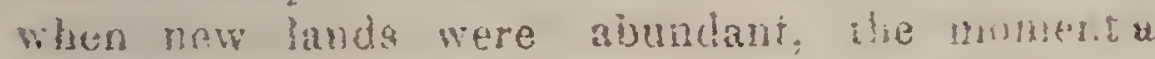

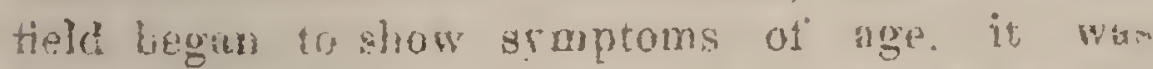
th:own 1! s., so give place to a nest plantation: bri, in lase years, since the scarcity. incleed. live tcisl want of wondland, has boen so severely cxperienced, it has bern decmed expedient to ro:sort to manuring and nursing of the old fielis. And since the application ut guano has betin bricu, and its powers as a renoralor to lhe suil made known; planters have pxpended some care ard attention, and applich their skill to the regeneration of old propertics. But as lie Guann is a rery expensive manure (considering irs cariage to bigh propertics and as its propullies rio not prove to be of so durable a nalure. as was anticipated, it has nccurred to me thit a chraper and more eficacious manure night be otained by oruinary mears on plantations; such as the penming of slock, and oblaining their excrement, the saving of line Coffee puip and uf the fan trash. A combination of the pioner. res of ibs thrue manures, proves a most etlectual renovator to a reclining soil; a fact which is to be evillenced in the richurss and hraurange of the trees, whenever the Coffine yilp or trash has hesen wastued aboni, their rone by the sabis I hese mepeatedis trien lis manure on old fields under ny own superintes-

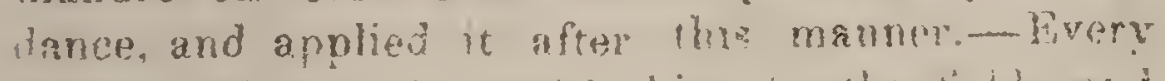

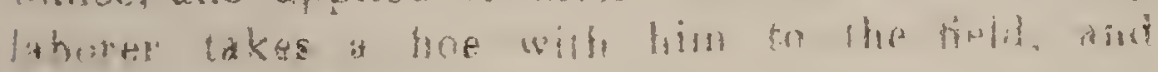




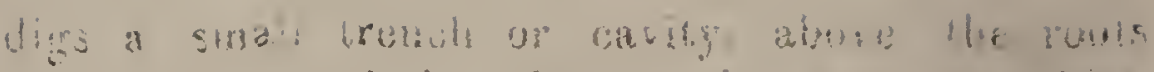
of the trees and then inserts the manure, whon is covered by the loosa earth. The first heavy shower of rain is sure to wath the munare into the roots of the tree, and the latter derivos all its benefits by a suction of the quartiy so aprylled. But it the people be allowed their own way, they are too apt to insert the manure leveath the trese, and thus it is washer awal, and its suckion draw to the centre of the rok, 1.1 generate weeds, without benefiting the objoct. for which is was intended.

On properties where there are witer works, the Culfee pulp is generally carred away, bit rmeans of a smali woder gutier, into the cus way, where the water whel plays: and the fan trash in most. instances, is blown away from the funner into the olyer cut way where the water whel which turns she grindine aill, flays. This system. to say the leant of 11 , ia a great waste and ahould be achadoned. The Collece pulp shoubl be returned to the soil, whose nutrituve powers have heen salled into action to generate 3t, in the samo manuer as the cane trash is remued to the sol on extates.

"The indications of bearing are lasualy in by seen in swelling of the frints, ant the hang. ing down of the lowes, whence the burl issues. Whe bivtiom has been kept in this statu for wenks, aye nonths, fron dry wartier; but the moment a shower of rain satis. wist aronishing rapiltity, the bud shoots, and in two days affer, the fioh will present one mass of snow whiteness---the fragrance of which is gratefu to

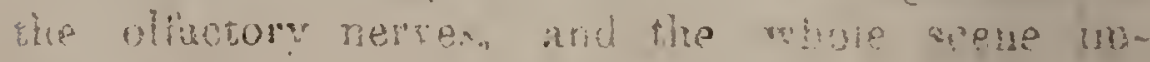
pary 


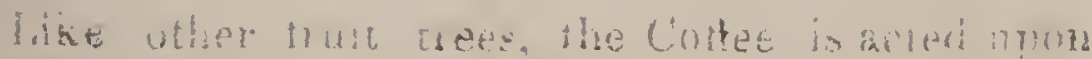
by the seasors, and the ate and early blossoms lecomes comingent rpon them. In wam disunicts the Marih blossom is most balculated or... anltrough fxpectations tor at crop are not given over, thl May has passed away. In the colder reguions blossoming may commence in March or Moy, which is considered enrly; hut July and Aliguet give strongest aud nost general blnssoms. 1 have, however, seen large lobsoms in septemher and Uctober. such being the peculias changes brought about by the seasons. Three gnod blossoras are ksualy looked for, but I have known goud crops, made of cne heavy and reguiar blossom.

Coffee blossoms shoot out in bunches, not unJike those of the Spauish Jasmine..-but they decay in the course of two days, when the fruit is supposed to be set, and formed upon each hussun-the latter cither drying, or, in heavy runc, falling off the tree. In cold climates the ficlus will by seen for months in a cominual spitting blossum, and yet no fmit revuls-as the blossoms are chilled previous to sctfing: and sometines the young frnit, after being formed, becomes chilled, turns black, and drops ofr.

In wam dimates the frut alvanres rajilly, abd in the course of a month will bave grown lo the sise of a sriall pea; hut in could locaHues, two months will rapee before it bas alruved at that siage, While the frut is young till the kerne? begins to form, it wlll resist the infuence of iny weather; but after that yerior

n ciroops, and feels much the want of mosture,

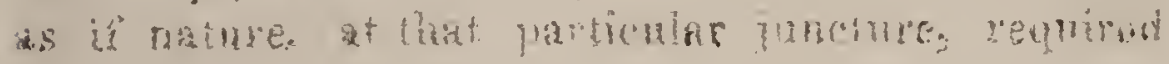




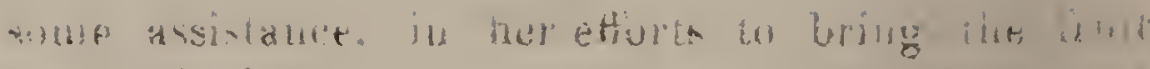
10 pertection.

From the lime of the blossom to the realuge of the fruit, seven months may bo allorted as tho probationarv term; but I have seen a crow gothered in trom a six momhs blossom. Whou the seasons have been favorable: and, th the upper mountains. I have known fruit to we reaped in from an eight inout:s' bosson.

the Coffee begias to ripen in warm distruts in August-mbut in cold places in lotmary, a: which period the former crap ts finished whilst. in the iatter it lasts to August.

ON THE MANTHACTHE OT BOHFE

The manufacture ot this staple comodity. will a view to its implovement in quality, is a subm ject, which demands our serious atuntion. aut when we observe the vase importance and protwiary advantage which accrue upon the slightest shade of improvempnt either in colour or appear. ance, it becomes the more imperaire ull us to use all those means which are availuhle, in orife to place ourselves on a footing with the forejun grower. It is true that we are unable to enter the contest with the East Indian or glave cult?vation, from the abundance and cheapuess a labor which is placed at their eommand: bu by manus of our skill and assichity re can sum

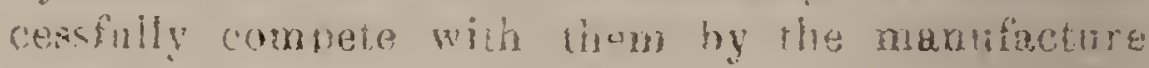
of enperior produce.

Tin this portion of Hantation mangegenon, I.

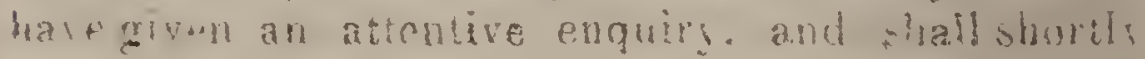

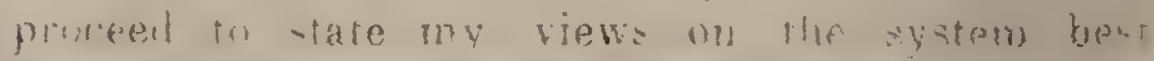

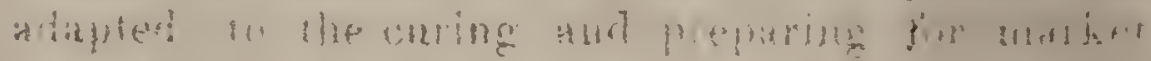

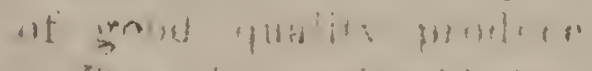


bivol ripe stisit. to all appearance like cherrien The laborery are principally accistomed io pay the crop in baskets, of which they carry lwo lo live jels: and when the coffee is bearing hearily and is at its full stage of ripeness, the good pukcrs will gather in fou bushels per diem.... and cary the same on thair heads to the works.

The fruit is then measmred and thrown into at loft above the pulper in a heap. It shombl be submitted to the first process of machinery-tinc pulper-within twenty four hours after, if not immediate!y-but it not unfreguently happens thet the manager is mable to mulp his cothe for two and sometimes three days, by whici time fermentation ensues, and it becomes impossible after puiping, to wash off the mucilage. which ratie: atheres to the out" unvelope ot the berry, and gives the produce what is tormed a "red" or "blankety" appearance, whon pread out un the Barbacues. The produce is lot down, by means of a small hole cut into the Hoon of the loft, on a Hoating bos: into the holper of tho pulper, and by mears of a grato: foring the fruit against the chops, the berries are disholged from the puly, and fall whon at gieve, which being shook by the machinery lets the beriere fril into the cisiern - whilst the grator ratches be pulp, and corries it hatkinards, at each evolution of the roller, around which ir is ancircled.

The fruit which way have punsed ihrownh willout being more than bali squepert, and iste ing only ejected one bermy, is then rebuned, (atter being shason off hy the sien?) sutc the

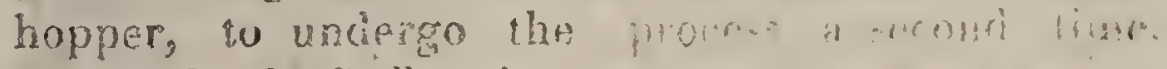
The pulrea Coffie ic 


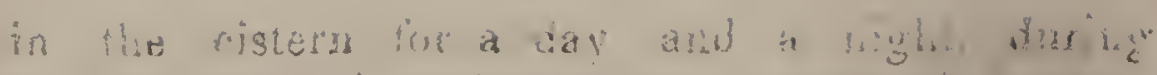
whin period it undergoss a prowes ot termmanation, -it is then washed out in two or thees waters, and the whole of the muriaginens anfl which had risen fiom the berry by fermentacionis entirely washedoff, and the Cofee presents a beatiful white appearance. From this the froduce is returned out to drain in a barbacues sloped so as to throw all the water to the centre, where a drain is placed to carry it all off.

It an hour or so after, the Coffee may bo removed to the barbacues for curing, -it is there spread out thinly, and exposed to the sim, which if shining strong, will, in eight or nine hours, absorb all the water, and the Coffec bo tht for bousing that day. I say fit for housing, because I have repeatedly seen Cofree wahed ont early in the morning, and put up the same evering. I cannot say I approve of the system, though in fint weather it has been atterded with success. From the time the Coffere is first exprosed to the sun till the silver strin strrts, is the stage, in my opinion, during which the produce suffers most injury. In the firat instance, it should be kept constantiy tumed, in order to get the water arsophed as eariy as possible; and after it has been housed, the greatest precantion should be taken to preveut its heating; and it is for this I disapplove of early housing, for if we weather should intervene, and the Cotfre cannot ie turued ont, it is sure to get hooted. From this neglect, I have secn a purfort stearn ring from the house in the morning when the dors have been opened, and I have known, as a natural conscinence, the adiesion of thas siver

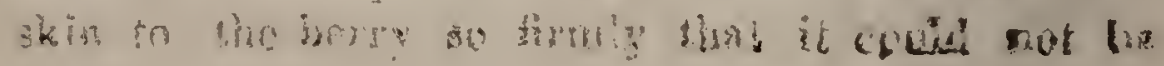




\section{$\left(33^{\prime}\right)$}

rexcoved by a sharp pen-knife, without slicing the berry.

In a series of wet weather the produce bas remained on the barbacues for several weeks, without the slightest advance in curing; and, unless it be frequently turned, while in this wet. state, it is sure to grow, - the berries first swell, then a thin white spire isssues from the seam, and on opening the berry, the young leaves will be astually seen formed inside-so rapid is the course of vegetation.

I am of opinion that Coffee should not be housed, till the silver skin begins to start, when no danger can ensue; for if a few wet days should intervene, by turning the Coffee over in the house, and allowing a current of air to pass through it, it will keep four weeks. It is at this stage that the parchment skin begins to show itself; for at first, it adheres to the inner kernel; but the heat of the sur starts it from its lold, and it separates-thus on shaking a handful of the produce, it will be heard to rat tle-a sure indication, that the silver skin has risen from the bean, without even threshing it to ascertain the fact. The bean is perfectly white, till the silver skin starts-it then begins gradually to assume the dark, or what is called the half cured appearance. A gand day's strong sun will then half cure it, and by subsequent exposure, the produce takes another stage, and gradually loses the half cured, and assumes a blue color-and when the produce is properly cured, and fit for the mill, nor the slightest dark spot will be perceplible in the bean but it will exhibit a tinny blue color.

It is within rny observation thes Coffee has 


\section{( 34 )}

been gathered from the field on the Monday, and prepared for market on the Saturday, in a spell of diry weather: I have known it also to lay on the Barbacues for as many weeks in contrary weather, before it had gone through the same ordeal. Wilh good weather and smooth terraces whereon to cure, nothing but gross and unpardonable carelessness, can produce bad quality of coffce. The difficulty arises in wet weather, when one's skill and aseiduity is called into action, to save the produce from being spoiled. After Coffee has ween haif cured, the putting it up hot at an early period of the day, has the effect of curiug it all night. I have noticed produce housed in this manner, and requiring another day's exposure to fit it for the mill.

The Barbacues should be kept in good order-all ruts and holes neatly patched every crop, for to them and other roughnesses is to be atattributed the peeling of the berries, their being scratched, and other injuries which the produce sustains. And while on the sulject of "Works" I cannot help noticing the extreme carelessness and inattention which, in visiting properties, the works and buildings present to our view. It is utterly impossible to mamufinctire gond produce, unless the machinery and buildiuge are kept in good order, and the parsineny which is thus displayed in this necessary mitay is fallacious, when one thinks of the result of nne or two whillings per 100lbs. lost on a ... f e brough this neglect.

When the crop is parfocify ont? which is generally ascertained by threster ous a few

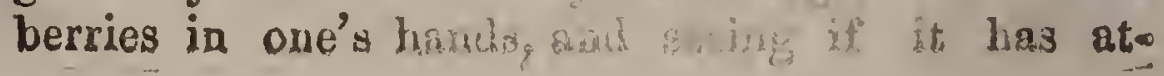




\section{$(35)$}

tained its heavy blue color-it is then fit for milling, which is the second process of machinery which it has to indergo. Here the parchment and silver skins, are dislodged from the berry, by means of the friction of a large rollor passing over the produce in a wooden trough, It is then thken out of the trough, aud submitted to the fanner, or winnowing machine. when the trash is all blown away and the coftic passing two or three sieves comes away perfectiy clean, and partially sized. From this it is aguin served in order 10 size it properly, hand-picked, put into bags, and sent on mules' backs to the barquadier. It is then put into tierces, and sold in the Kingston Market, or slipped to Britain.

A variety of circumstances tend to injure the quality of the coffee, which it is beyond human agency to control. Dry weather intervening at the particular period, when the berry is geting full, subjects it to be stinted and shrivelled, and strong dry breczes happening at the same period, will cause an adhesion of the silver skin, which the ordinary process of curing and manufrcture will not remove. Late discoveries in the latter, have however, shown the possibility of divesting the produce of that silvery appearance when brought about under the foregoing circumstances. It is almost umnecessary to state that this improvemont in manufacture refer's to the inventions of Messis. Myers aod Mcacock, whose respective merits have already uudergone public revision. In reference to Mr. Myer's plan of immersing coffee in warm water I may be allowed to state, that it has come under my own observaticin, that produce 
which had previously been heated through some carelessuess in the curing, subsequently was exposed to a slight sprinkling of rain, and when ground out, and fanned, was found to have lost its silvery appearance.

'To the invention of Mr. Meacock, a preference has, however, been given, in consequence of the impression that the produce thus inlmersed in water, will absorb a portion of the liquid, which will deteriorate its quality in its passage across the Atlantic. Several Gentlemen have shipped coffee submitted to this process to England, but I have not learnt the result.

I do not mean, however, in this essay to enter into a disquisition of the merits of the respective claimants to this beneficial invention in manufacture. Suffice is to say, it appears very manifest that a great deal might be done in the way of machinery, to relieve produce of that silvery and foxy appearances, which are so prejudicial to its value in the British market, and which appearances might accrue from 'a variety of incidents, to which all plantations are more or less subject.

A manifest preference is given in the leading European markets to Coffee which has gone through the pulping and washing process; but strange to say, the consumers of this beverage are totally ignorant of the fact, that the prodnco which is cured in the pulp, furnishes a stronger decoction, than an equal quantiry of the same, which has undergono the othar process. Many persons are of opinion, that the mucilaginous substance which is vashed of in putpirg, is absorbed by the bean, when cured in the pulp, 


\section{$(37)$}

and which gives strength to the produce, ant? enhances iis arumatic flavour. On most properties, it had boen customary, to cure the remnants of the crop in this way, for the use of the plantation; ant it has been well noticed by great epicures in the ftaver of the deroction, that the Cofiee thus cured, produced the strongest and hest beverage.

With regard to the use of Coffee as a beverage, it has had its adrnircrs and detractors. Is the East, it has been the subject of many a rilliculous controversy. The Turks believe thit the infusion of Coffee was invented by the $\Lambda \mathrm{n}$. gel Gabiel, to restore the healin of their Prom phet, Mahomet. In Europe, it has been pronounced by some as injurious to health, whilst nhers talk of its virtues with enthusiasm; but tho extended use of this beverage in Europe during the last ten years is of itself sufficient testimony of its salutary qualities, and mus: negntive the assertions of its detractors. On chemical analysic, it has been found to contain an acid or crummy substance, a resinons abci astringent extract, a considerable proporion of oil, and sone ammonia and other salts. The action of firo destroys its crude and watery taste, and renders the oil empyreumalic. When prepared for the table, it has established for itselt, the character of aiding digfestion, and has a marked effect on the nervous systen, in removing lingour and drowsiness, end in favoring a pleasant cheorfuhess, friendly to socialify, wit, and good humour. The lurts, on going to battie, or on atiy emerones, am ploy opium to excite their spirits, and to star. dy thin couragr, -io relitie the langour con. 


\section{$(38)$}

sequent thereon, Coffee is the specific which they ernploy.

The Orientals prepare their infusion very thick, and drink it very warm, without milk or sugar, merely flavored with some aromatic or perfume. The Persians used to prepare an infusion from the dried berly, without removing the pulp. The 'Surks again preserve the pulp after it has been separated from the secd, and having dried it, procure from it an agreenble heverage, resembling tea. They also use an infusion of the seed, without being roastedor they roast it, but yreserve the berry entire in the infusion

The most common mode now generally alopted for preparing Coffee for the table, is to roust the berries in an open iron vessel, over an equal slow fre, and kept constantly turned luring the process. It ought to be withdrawn from the fire, so soon as the smell informs us that the Cofiee has begun to burn, and when it has acquired a color not unlike that of 10bacco. It ought then to be cooled as rapinly as jossible, by exposing it freely to the air in some cool vessel. When perfectly cold, it is to be placed in the mill, and ground to a fne power-which, infused in boiling water. in the proportion of half an onnce to two onnces af water, produces a most delightful and acreeable beverara. 


\section{ATNIDI.}

[N re-printing Marah's useful Essay w have determined to add to its value by appending a ferw articles of more or less interest in connection with the Coffee Trade of Ceylon; and which, in a collected form, will be useful for reference.

Entors Coloneo Observerm]

lirom the Colombo Observer, Mareh 19, 1849.) CHICORY.

To a Mercantile Friend we are indebted for permission to copy a document of the highest interest to our Planting friends and indeed to every one connected with Coylon. There is no escape from the position taken by the Memorialists:-that so long as the Customs duty on Cofiee is retained, an equivalent excise ought to be levied on its competitor.

$$
\text { "Liondon, lst.January, } 1849 .
$$

With reference to the present anomalons position of Coffee, as exhibited in the anrexed account, we beg to give the substance of a Memorial now before the Lords of the Treasury and the Board of Trade, tracing it to the footing on which Clis. cory is at present placed, and surgesting the remedies, that wilhout any furhes holay, ought to be applied. 
"In Sugar, according to the annexed Table, a fall in price since 1814 , of $24 ;$ per cent. has been attended by an increace in the consumption of 46 per cent. In Coffee on the contrary, with a reduction in the price since 1846, of 15 to 22 per cent. on duty paid descriptions, the consumption has not only not increased at at corresponding rate, but has for the last three years come to a complete stand still, being last year only 38.85 million los., that is to say no more than in 1846 , and 5 of a million lbs. less than in $184 \%$. The revenue derived from Coffee has in consequence also fallen off from $£ 756,838$ in 1846 , to about 2710,069 in 1848. During these three years, there has, with priec: almost stationary, been some increase in the consumption of Cocoa and Tea. $T_{11}$ the former it has progressed from $2 \cdot(j$ million lbs. in 1846 , to 3.96 million lbs. last year. In Tea, as the increase in the consumption which last year exhibits is more apparent than real, it will be fairer. to take the avernge of the last two years, which is 47.42 million lbs. or about is per cent. more than in 1846 . It will be seen that, although, even with stationary yrices, there has been some increase in the consumption of these kindred articles, it is not by any means of such a character as in the slightest degree to account tor the falling off in Coflee."

"To what then is owng tho chrnges 


\section{( 41$)$}

that appears recently to have overtaken an article which, ever since 1784, has, more than any other, furnished our political cconomists with stiking instances in proof of the now generaily received doctrine, that every well considered reduction in the Import duties, will, by the increase in the consumption which follows it, evertually compensate the revenue for any temporary sacrifice it may have submittid. to in this process?"

"The cause of that change is sufficiently notorious, and the history of it is this:In Germany the root of the Chicorium Intybus, L. or Succory, a species of Lindive, indigenous also to our island, has for the lase forty years been prepared and sold on a large scale as a cheap substitute for Coffee. From Germany it was, thus prepared, subsequently also introduced into this country; but as a duty was levied apon it equal to that which Coffee paid, and as by 3 Geo. IV. cap. 53, the zale of any roasted vegetable substance in imitation of Coffee was, under a penalty of E50., restrieted to persons not being dealers in Coffee; the interest of our groceris was not then enlisted in pushing it into any extonsive use. The import duty on Foreign Chicory lod, however, in time, to the cultivation of that root here, and when in this way a supply of it, free of any duty, had grown up, means were found in Ancrust, $18 \pm 0$, to procure a Treasury order 
authorizing the Excise, for the future not to object to grocers selling Chicory, or mixing it with Coffee. The effect of this abrogation of the 3 Geo. IV., cap. 5:3, was speedily felt, and induced the impor.ters of Coffee in 1842 to complain of it to the Chancellor of the Exchequer. These representations however, unfortunately, had not the desired result, and the consequence is, that under the operation of the active demand on the part of the dealers, the produce of Native, duty free, Chicory, which Mr. McCulloch in 1842 estimated at 6.72 million lbs., has since at least doubled, and is to that extent now encroashing on the consumption of Coffee."

"And this is only what might have been expected, for while home-grown kiln-drical Chicory can be delivered at $2 \frac{1}{4}$ per lb. to the wholesale dealers, the average price of dutypaid Coffee is from 7d. to $9 \frac{1}{2} d$. per $1 b$. Accordingly, even respectable grocers add at ieast 2-oz. of Chicory to 14 of Coffee, while others make the mixture half and half. The most experienced officers of the Excise estimate the average proportion of Chicory in what is sold in the London shops for Coffee, at one third; in the manufacturing towns in the country it is said to be fully one half. What further portion of pure Chicory is elscwhere added to the mixture, it is impossible to say; but it is fact, that those descriptions of Coffee which will bear the greatest armixture of Chicory, such as Costa Rica and $\mathrm{J}$ aVia. enjoy, on that account, a marked pre- 


\section{$(43)$}

ference in the market, greatly to the detriment of the more delicately flavored Ceylon Coffe?"

"The interests of the public, of the colonists, and of the resenure, therefore alike require that the above cited $\mathrm{A}$ ct of 1822,3 Greo. IV. sap. 53, which has nevor been formally repeled, should again be put in full force. It is tre that this interference with Chicory has becis vaguely deprecated, on the plea that it in i "rative procuct," but so is the leaf of the slop: and so would Tobacco be, if the cultivation of that plant here had not been put a stup to. In these cases, the legislature has setis fit to decree proscriptions against "native prodiscte," and thcre is, therefore, nothing remunant to the principle on which our legisldion has hitherto proceeded in such matters in stting the 3 Geo. IV. cap. 53, takn its ourse-that course, be it observed, involving no moseription of the Chicory, but mer. Iy a regulation of its sale. - Another plea in fivur of Chicory has been drawn from its alledgd wholesomeness, which has been murin adverzed in Germany. The truth is that it is simly diuretic, and the habitual use of it. must eaken in proportion to its power of actio'. ' $\mathrm{I}$ is refers to genuine Chicory, bnt wh at is sold tothe retaileras such is a mixture, agyanst the whlesomeness of which the very sirondest presmption is justifiable, and the mont respectale wholesale houses have felt this so strongly: as to induen them to take into their own hals the manufacture of the Chicor? which thy sell, purchasing themselves the root ats kilntying it on their own premises. 


\section{( A )}

"Estimating the proportion in which Chonry at present enters into what is sold a. Coffee, at the low rate of onn libird, it follows that, along with the 36.85 millions lbs. of Coffee ronsumed last year, 1228 millions lbs. of Chirony have been sold. It the sile of Clicory should again, in confomity with 3 Geo. IV. cap. 53, be restricted to persons, not reing cendors of Cofree, and taling out an amanl ficense for that puypse, the consurners rould dgain be left to make their own mixture of thre tro ingredients. In that case, it i believcd, that they won?d at most, mix only balf is much Chicory will their coffee the urocers at prescit do. The affect woul be, that abont six millions lbs. loss of Chiony, but the same quantity more of Coffec rould be consumed; conscgnently, fint on ofice srowers vould find a vent for six milios lls. Fnore of their produce here, and that a alhitioual annual revonue of at lenst $\mathcal{E} \mathrm{i} 0,000$ sonki flow into the Exchegner, tha curpt of which has for the present been diverted into wher channcls."

"Thit heing the case it is diment icclisenver on what grounds it can posshly ary lower be Acrined, to give renewed cfice to the Geo. IV., cap. 5s, the suspension of whithas alrendy oferated sovery mischiovolaly?

"Dut though this wonld gonome wyowars sctting matters richt, it would nothy any uneans meet the case fally. So far as lie pablic and the revenue are conecrned, is qresfion may be one of mere expedienc; but as reenorls the Colonists, it is csontinl one of I.inciple. Justice tomards them obcusly du- 


\section{新)}

mands, that thcse our fellow subjects should be placed on the same footing as the cultivators of Chicory at bome, and that, therefore, the Excise should levy the same duy on homemrown Chicory, as the Customs do on British Plantation Cufice, while Foreign Chicory ought to pay the same duty as Forcign Coffee. This is so clearly the case,- is so necessary a consequence of our wholo present system of col, ninl and commercial policy, and wonld at the same time, be attended by fiecal results so sccertable, that it is needless to do more than merely cnounce the proposition, in order to obtain a goneral assent to it. In the case of Sugar, Parliament has, in fart, cver since 1837, recognized and acted on the principle of it. By the 1 Vic. cap. 57, the same duly was imposed on horne-made Sugar from Beer-root, as on Britibly Plantation Stigar from the Cann, and by 3 and 4 Vic. cap. 57 , the atplimtion of the former act was extended to home-mide Sugar from any substance whatower. Thint- fact must be regarled os settling the givestion, for no one will argue that our Colfure planters are not entitled to the same neasure of justice as cur Suga: plantors, and granting this is to frrant all that is here contended for.

- "We present duty on Foreign raw or kilndienl Chicery is 20s. per Cwt., and on roated or ground ditto, fil. per the, and the clearances for collumptinn of it in London amolnted in

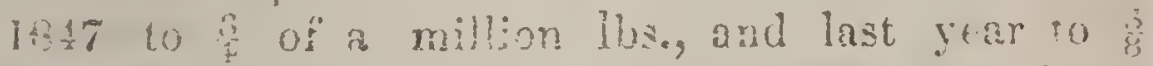
(f) a million lbs. sielding a very insignificant revenur.-.The gross excise duty cullected on honumade suerer at the rate of 21.5 , per Cwt, up to Aijril, 18t5; and 14s. subsontentiy, averaged 


\section{$(46)$}

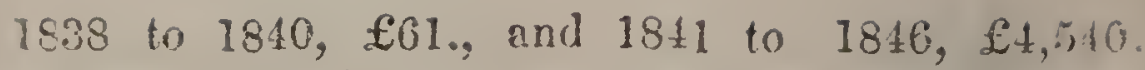
a year, but fell in 1847 to $£ 169$ - An Exrise duty equal to $4 \mathrm{~d}$. per $\mathrm{lb}$. On home-grown roxsted Chicory, would either produce not far from $£ 200,000$, annually, or, if it checked the consumption of Chicory, the blank would be filled up either by British Plantation Coffee, paying $4 d$. or, by Foregn Cnffee paying 6d, per $1 b$. Cus.. tom's duty. In either way the revenue would be benefited to a very considerable amount."

\section{JAMES COOK \& CO. 40, Mincing Lune.}

(From the Colombo Obscrier March ag) EXPORT OF COFFEE.

Nemorandum of Coffee exported from Ceylun from the year 1836 to 1818, inclusive.

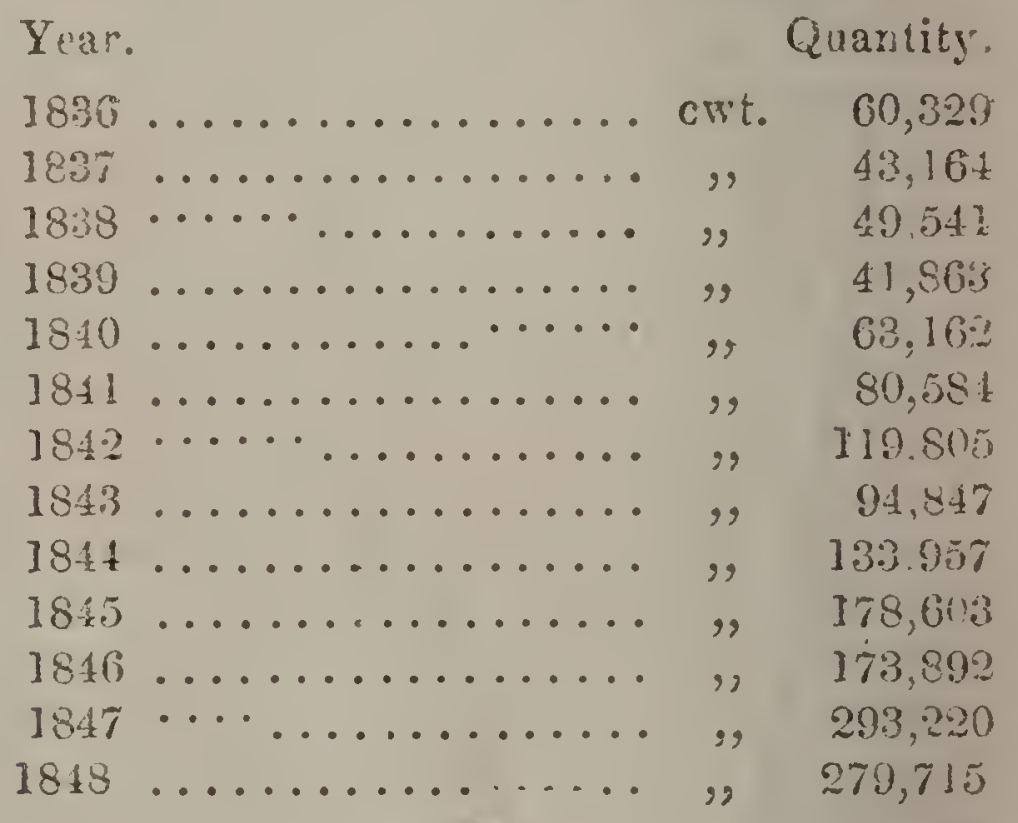

(Fram the Culombo Observer March 22,) Wur 
COPIER AND CHICOTEY.

Our readers will he infested by the following clathrate statement of lin. Imp ont, Price, and Consumption of Coffee, framed

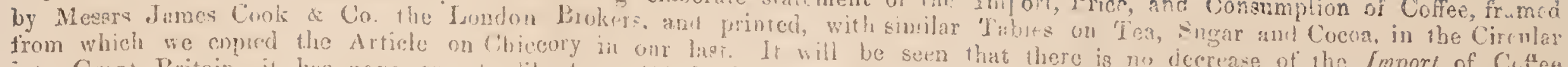

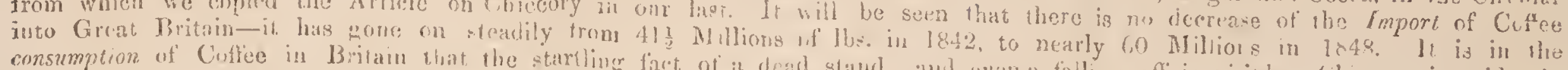

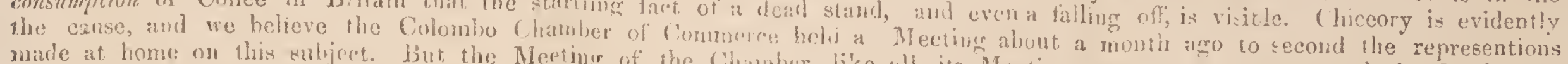
left in the dark as to the action baleen or recommended. As it is important to bring together all one, and the Public are

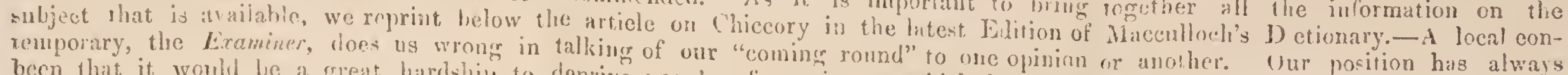

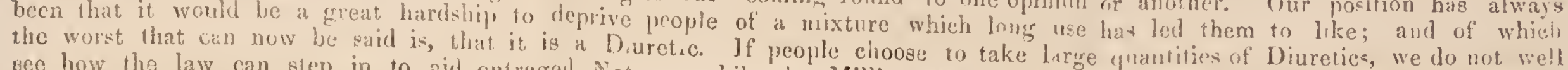

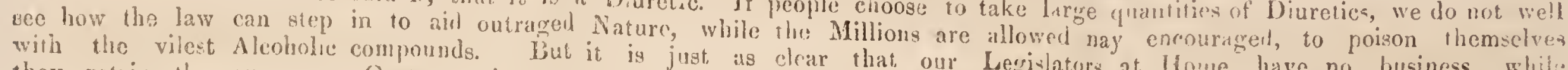

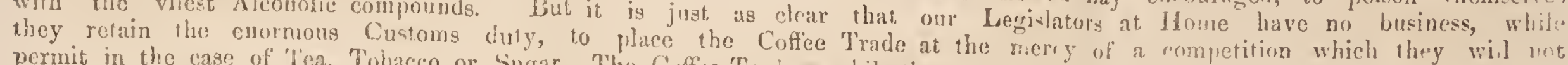

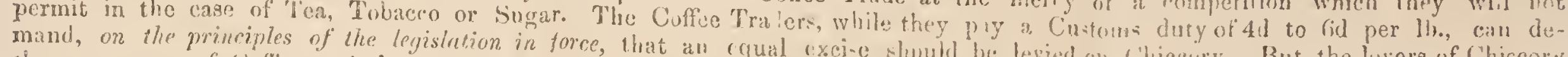

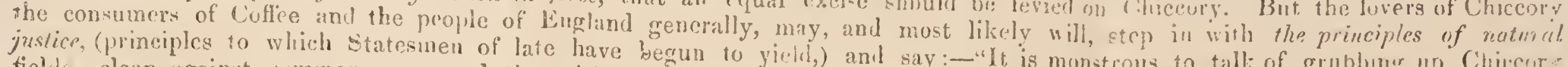
fields -clean against common sense and the spirit of the age; nut it is quite right that Coffee should be it. once relieved fum
the heavy Customs impost. I The loss of Revenue must be made un by retrenchment." "Lo this complexion" the matter. "ming roe, or ut a rift no dur. who insist that they who profess to all who agitate the subject should he prepared. At the same time, we go fully with these

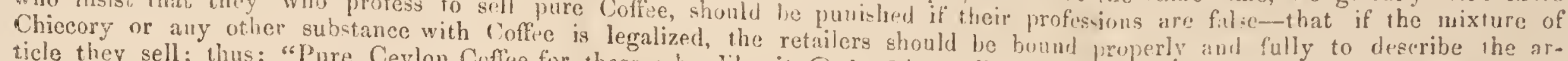
cory 101 per lb." Such a course would be fair and above it (1) is $2 \mathrm{~d}$ per Ib."-"Ceylon Coff e mix tel with $\frac{1}{4}$ of gond ChicThe law does not say "You shall sell your $4 \mathrm{lh}$. loaf at a certain price; but if you profess to sol a loss containing $4 \mathrm{lb}$. of good wheaten Hour, we shall punish you for light, weight or the mixture of inferior or deleterious cubstarees."

$\mathrm{C}$ E E E, (United Kingdom.)

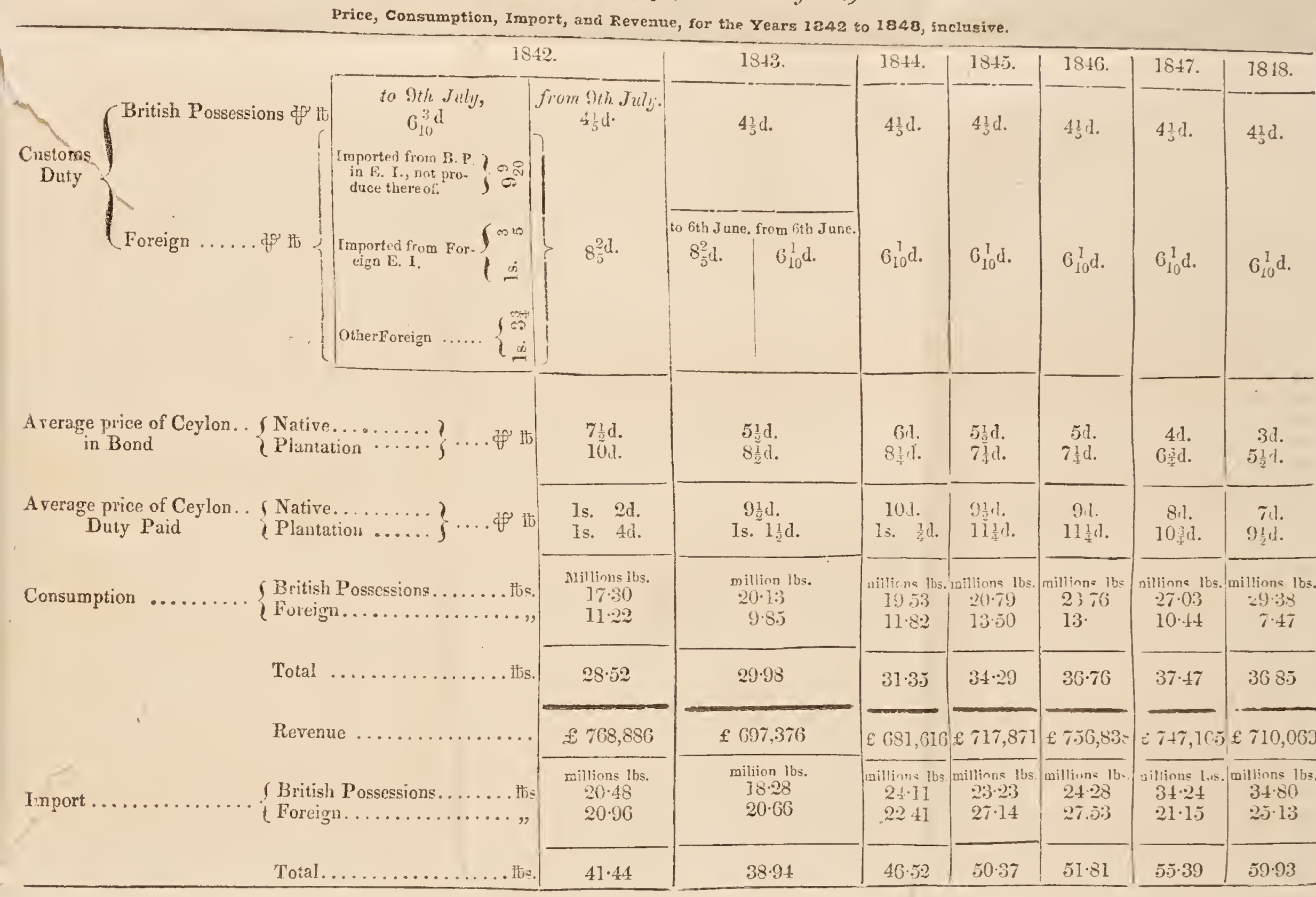

(From Maccullocli's Dictionary of Commerce.)

CHICCORY of SUCCORY, the wild endive, or Cichoriam Iulus of Linnæus. This plant is found growing will mn micareous soils in England, and in most countries of Europe. In its natural state the stem rises from 1 to 3 feet high, but when cultivated it shoots to the height of 5 or motherlands and France, chiccory has long been extensively cultivated for the sake of its root, which is used as a substitute for coffee. When pref-

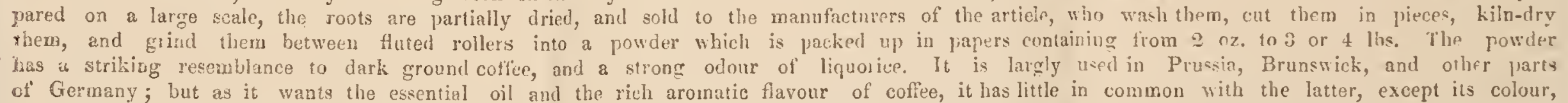
and has nothing to recommend it except its cheapness.

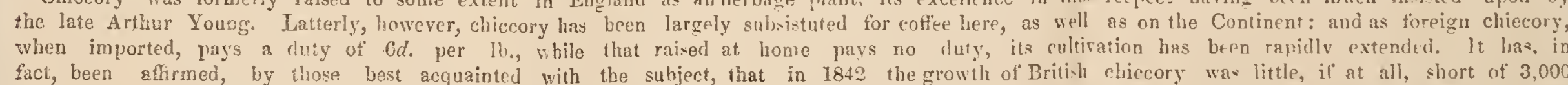

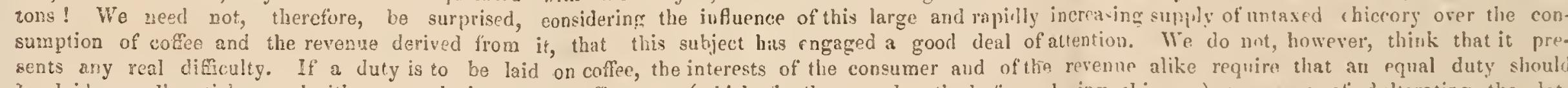
be laid on all articles used either as substitutes for coffee, or (which is the usual methorl of employing chiccory) as means of adulterating the lat-
ter. We are well convinced that the substitution of chiccory for coffee has already occasioned a loss to the revenue of 100,000 . a year, besides its

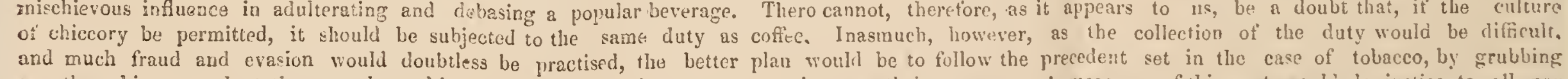
up the chiccory plantations, and making, at the same time, compensation to their owners. A measure of this sort would do justice to all pare 



\section{( 47 )}

(Extracts Froit the atticle "Coftee" in MacCullocii's Dictionary : EDItion of 1847.)

CoFfe (Ger. Knffee, Koffebohnen; DI. Kaffy, Kopiboonen; Da. Kuffe, Kaffebörner; Sw. Koffe; Fr. It. and Port. Café; Sp. Café; Kus. Kofé; Pol. Kaua; Lat. Coffea, Caffea; Arab, Bun; Malay, $\overline{s i}$. wa; Pers. I'ochem, Kéwéh; 'I'urk (haube), the berries of the coffee plant (Coffer Arabica Lin.) They are generally of an oval form, smaller than a horsebean, and of a tough, close, and hard texture; they are prominent on the one side and flattened on the other, having a deeply marked furrow running lengthwise along the flattened sicie; they are moderately heavy, of a greeuish colour, and a somewhat bitterish taste.

Progressive Consumption of Coffee in Great Britain. Tinfuence of the Duties. In 1t,60, a duty of $4 d$ a gallon was laid on all coffee made and sold. Previously to 1732 , the duty on coffee amounted 10 $2 s$ a pound; but an act was then passed in compliance with the solicitations of the West India planters, redacing the duty to Is $6 d$ a pound; at which it stood for man ny years, producing, at an average about $£ 10,000$ a year. In consequence, however, of the prevalence of smuggling, raused by the too great magnitude of the duty, the revenue declined, in 1783 , to $£ 2,869103$ 


\section{$(48)$}

10 1 d. And it having been found impossibie otherwise to check the practice of clandestine importation, the duty was reduced, in 1784, to 61 . The consequences of this wise and salutary measure were most beneficial. Instead of being reduced, the revenue was immediately raised to near three times its previous amount, or to $£ 7,200$ 15s $3 d$, showing that the consumption of legally imported coffee must have increased in about a ninefold proportion? -a striking and conclusive proof, as Mir. Bryan Eilwards has observed, of the effict of heavy taxation in defeating its nwa oljoct.-(Fist. of the West Indies, vol. ii. p. 3i0. 8 vo. ed.)

The hisiory of the coffee trade abounds with similar and even more striking cxamples of the superior productiveness of low duties. In 1807, the duty was is 94 a pound; and the quantity entered for home consumption amounted to $1,170,361$ $1 \mathrm{be}$, yiclding a revenue of $161,2451,11 \mathrm{~s} .4 \mathrm{l}$. In 1808, the duty wa reduced from $1 \mathrm{~s}$. 8 it. to 7l.; and in 1809 , no fewer than $9,251,817$ lbs. werc entered for home consumption: viclding, notwithstanding the redurtion if duty, a revenue of $245,8561,8 \mathrm{~s}$. $4 \mathrm{~d}$. Tho duty having been rajed, in 1819, from 7d. to ls. a pound, the quantity cutered for home consumption, in 1824 , was. $7,993,041$ 11 s., yielding a revenue of $407,5441.43 .31$. In 1824, however, the duty being agrin reduced from Is. to 6a, the quantity cntered 
for home consumption, in 1825, was $10,766,112 \mathrm{lbs}$, and in 1831 it had increased to $22,740,627$ lbs., yielding a nett revenue of $583,751 \mathfrak{L}$.

The rapid increase in the consumption from 1825 to 1832 must not, however, be wholly ascribed to the reduction of the duty. This, no doubt, had the greatest influence; lut a good deal is also owing to the low price of coffee from 1824 to 1830 : and also to the great reduction during the same period in the price of low brown sugar (fully $1 \frac{1}{2}$ d. per pound), a cheap and abundant supply of which is so indispensable to the extensive use of coffee.

These statements, which are principally deduced from the accompanying account, No. II. includes the United Kingdom, and is brought down to 1844 . The most remarkable features in this account are the reduction of the duty on coffee from the East Indies and Ceylon to the same level as that on cofiee from the West Indies, and the farther reduction of the duty on coffee from British possessions in 1812 to $4 \frac{1}{3} \mathrm{~d}$. per $1 \mathrm{~b}$. The equalisation of the duty on East and West India coffete had become indispensable after the ralid decline in the supplies from the $W$ est Indies consequent to the emancipation of the slaves: for, as foreign coffee is burdened with a high discriminating duty, the price of British coffec must ntherwise have risen to such a leight as materially to interfere with the 
nonsumption. The latter, indecd, has nøt increased since 1832 , in the ratio which wnight have been expected from the increasing wealth and population of the country, and, in fact, rather declined during the years 1840, 1841, and 1842: This result was no doubt in part to be ascribed to the then comparatively depressed situation of the manufacturing classes; but we believe that it was mainly owing to the admixture of chiccory, and other matters, with coffee. We have already seen (art. Ciriccory) the extent to which chiccory is produced free of duty in this country, and the rapid increase of its culture; and as it is wholly used as a substitute for coffee, or rather as a means for its adulteration, we need not be surprised at the stationary consumption of the latter, even with low prices and a reduced duty. It is, indeed, indispensable, if we would do justice to the coffee planters, and protect the revenue, either to lay the same duty on chiccory that is laid on coffee, or if that be impracticable, to grub up the chiccory plantations, on making compensation to their ownters. But exclusive of chiccory, it is affirmed, and we believe traly, that otlier and more objectionabje substan. ces have latterly been extensively $\mathrm{cm}$ ployed in the adulteration of coffee. Something, perhaps, may be done to obviate buch frauds by increased vigilance on the 
part of the police and the revenue officers: but the only effectual remedy is to buy coffee before it is ground; and as a mill for grinding may be bought for a small sum, and coffee is sold ready 'roasted, there is, in this way, no great difficulty in obviating adulteration. Those who use ground coffee will also be secure against traud if they resort only to shops of the highest character.

We observed in the former edition of this work, that "sound policy would seem to suggest that the duty on foreign coffee should be materiaily reduced; for though it be absolutely less now thah formerly. it amounts to $82 /$ d. per pound, being double that on coffee from a British pozsession. But its reduction to about $6 \mathrm{~d}$. per pound, at the same time that it would allow Brazil and wher foreign coffec to be freely entered for concumption in the event of the supJly of British colonial coffee becoming defucient, rising in price, would leave a protection of no less than 50 per cent. in favour of the latter; which surely is as much as can be conceded with any due regard to the interests of the consumer." And we are glad to have to state that, in 1814, the duty on foreign coffee was ruduced to $61 / 10 \mathrm{l}$. per $1 b$.

The introduction of tea and coffee, it has been well remarked, "has led to the most wonderful chenge that ever took place in the dict of molern civilised nations, 


\section{(}

-a ehange highly important bolh in a moral aid physical point of view. These beverages lave the admiralle advantage of affurding stimulus withont producing intoxication, or any of its evil conseruences. Lovers of tea or coffee are, in fact, rarely drinkers; and hence the uee of these beverages has lenefited both manners and morals" - (Scotsman, 17th of Octoher. 18:7) So early as 1710 , the famous Lain poet Vanierius described the preparation and enlogised the virtues of coffee.

"illo medicamine vates

Tngenium emendet, lætusque intacia resumet

Catmina; nec fontus allios, yuibus ora poetr Proluerint, Ruxisse solo male credet Achivo."

Lib xi. p. 272. ed. 174.

Supply and Consumption of Coffer.-Owing to the increasing consumption of Cotfee in this country, the Continent, and Ame. rica, the great value of the article, the large amount of capital and labonl employed in its production, and the shipping required for its transport, it has become a commodity of primary commercial inportance. It dessrves particular ittention, too, inasmuch as there are few, if any, articles that cxlibit such variaticns, not only as to consumption, but also as to growth and price. Whese are occasioned - parly by clianges of commercial regulations and dutio, and partly, also, by the 
piant requiring 4 or 5 years before it comes to bear; so that the supply is neither suddenly increased when the demand increases, nor diminished when it falls off. St. Domingo used formerly to be one of the greatest sources of supply, having exported, in 1786 , about 35,000 tons; and it is supposed that, but for the negro insurrection which broke out in 1792 , the exports of that year would have amounted to 42,000 tons. 'The devastation occasioned by this event calsed, for a series of years, an almost total cessation of supplies. They have again, however, increased, and are understood to amount, at present, to about 15,000 tons a year. From Cuba, the exports of coffee have, for some years, owing partly to an increased consumption in the island, and partly to the efforts of the planters having been wore directed to the cultivation of sugar, been comparatively slationary. They may at present amouni to about 22,000 tore, or, including Porto Rico, to 25,000 tone. In Java and Brazil, the culture of coffee has increased with unprecedented rapidity (see MA'tavia and Tro JANErRo); so much so, that the exlorts trom Java, which did not, a few years ago, exced 18,000 tons, now amount to at least 65,000: while those from $\mathrm{Bra-}$ zil, which have inereaged in an equal decrree, amount to about 80,000 tons. 'The growth of coftee in India and Ceylon has been very greatly in reased, enperials in 
the latter, where, within the last few years, the plantations have been so much extended, that it is believed their produce will very shortly equal the present consumption of the U. Kingdom. There has, no doubt, been a serious decrease in the exports of coffee from the British West Indies; the imports into the U. Kingdom having declined from 11,014 tons in 1832 to 4,147 do. 1844 ; but when reference is made to the whole supply, this diminution is but incongiderable.

Exports. Tons.

Mocha, Hodeiha, and other

Arabian ports........ 8,000

Java...............65,000

Sumatra, and other parts of

Foreign India ....... 8, 8,000

Brazil and the Spanish Main.80,000 Hayti ............... 15,000 Cuba and Porto Rico.......25.000 British West India colonies. . 4,000 India and Ceylon ........ 13,000 Dutch West Indies ....... . 5,000 French West Indies and the

Isle de Bourbon . . . . . . 8,000 231,000

Consumption. Tons.

Great Britain...........13,500 Netherlands and Holland ...40,500 Germany, Russia, and countries round the Balitic ....50,000 France, Spain, Italy, Turbey in Eurone, the T.e-

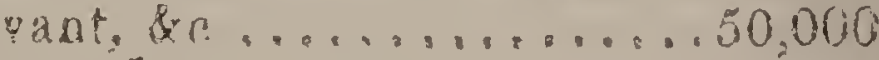


The United States ........45,000

Canada, Australia, \&c..... 8,000

207,000

Of the entire export of coffee from Arabia, not more, perhapo, than 4,000 or 5,000 tons finds its way to the places mentioned above; so that, supposing these estimates to be about correct, it follows that the supply of coffee at present exceeds the dewand by about 24,000 tons a-year. The latter, however, is rapidly increasing; and it is not easy to say whether it be destined to outrun, keep pace with, or fall short of the supply. On the whole, how. ever, we should be inclined to think, that though they may occasionally vary to the extent of a few thousand tons on the one side or the other, the probability is that the supply and demand will be preity nearly balanced; so that, supposing peace to be preserved, we do not anticipate any very great variation of price. When prices are considerably depressed, consumption is stimulated, and production checked, and conversely when prices are high. Oscillations will, no doubt, continue to take place in future, as they have done bitherto; but. unless the cost of producing cotfee should be seriously affected, which probably is not very likely, (unless some violent meissures should be adopted with respect to the slaves in Brazil,) they will not be unore than temporary.

The consumption of collee in the Lui 
ied States has increased with great rapidity since 1821 , in which year it arnounted to only 5,306 tons. Part of this increase is, no dosibt, to be ascribed to the reduction of the duty, first from is to 2 cents per pound, and its subsequent repeal; part to the fall in the price of coffee; and a part, perhaps, to the increase of temperance societies. Probably also, it was in some degree ascribable to the comparatively high duties formerly laid on the teas imported into the United States; these, however, finally ceased in 1833.

Coffee is sold in bond: the business beiag done in the public market either by private or public sales. It is always sold at landing weights and revenue tares; the latter being on casks, barrels, and boxes identical with the real tares, and an average rate on bales and bags. Draft is allowod for as follows; viz. on packages weighing under $1 \mathrm{cwt}, 1 \mathrm{lb} ., 1$ $\mathrm{cwt}$. and under $3 \mathrm{cwt} .2 \mathrm{lbs}$; $3 \mathrm{cwt}$. and under 5 cwt., 4 lbs.; and 5 cwt. and upwards $5 \mathrm{lb}$. Coffee is sold at a prompt of 1 month, allowing a discount of $2 \frac{1}{2}$ per cent. or 1 per cent. Thus the coffees of St. Dowingo. Harannah, and Brazil, (with the exception of the "plantation" variety of the last two), are sold at a discount of $2 \frac{1}{3}$ per cent., whereas all coffee of British plantations, or that liable to the low duty, including also the coffees of Laguayra, Costa Rica, "Plantation" Rio g. Mavannab, 
Mocha, Java, and other Kart India rarie. ties, are sold at a discount of 1 per ceut. The following Proforma aceount of the sale of coffee from Ceylon may be taken as representing coffee sold at a discount of 1 per cent., and that of the sale of Kio coffee as representing coftee sold at a discount of $2 \frac{2}{2}$ per cent.; but, of course, the freight and insurance would vary according to the port it came from. These sales are made out as if the goods were sold within one month from arrival. There is no charge for rent, as the consolidater rate covers that charge for 12 reeks. Coffee is always rent-free to the purchaser to the prompt day, and lies at the seller's riak till then, unless naid for.

Species of Coffee. Roasting, \&e.-The cutfees of Jamaica, Ceylon, and Mochu are generally esteemed the best: then follow the coffees of Costa Rica, Dominica, Berbice, Demerara, Bourbon, Java, Martinique and Hayti. Arabian or Mocha coffee is produced in a very dry climate, the best being raised upon mountainous slopes and sandy soils. The most fertile soils are not suitable for the growth of very fine coffee. Mr. Bryan Edwards observes, that "a rich deep soil, frequently ameliorated by showers will produce a luxuriant tree and a great crop; but the beans, which are large, and of a dingy green, prove, for many years, rank and vapid." And the same remark is anade by Mr. Crawfurd, with 


\section{( 58 )}

respect to the coffee of $\boldsymbol{J}_{\text {ava. }}$ (East Indian Archipelago, vol. i. p. 497.) Coffee is improved by being kept; it then becomes of a paler colour.

Mocha, or as it is commonly called, Turkey coffee, should be chosen of a greenish light olive hue, fresh and new, free from any mustiness, the berries of a middling size, clean, plump, and without any intermixture of sticks or other impurities. Particular care should be taken that it be not false packed. Good West India coffee should be of a greenish colour, fresh, free from any unpleasant smell, the berries small and unbroken.

Coffee berries readily imbibe, exhalations from other bodies, and thereby acquire an adventitious and disagreeable flavour. Sugar placed near coffee will, in a short time, so impregnate the berries, and injure their flavour, as to lower its value 10 or 20 per cent. Dr. Moseley mentions, that a few bags of pepper, on board a ship from India, spoiled a whole cargo of coffee.

"The roasting of the berry to a proper degree requires great nicety: the virtue and agreeableness of the drink depend upon it; and both are often injured by the ordinary method. Bernier says, when he was at Cairo, where coffee is so much used, he was assured by the best judges, that there were only two people in that great city who understood how to prepare it in perfection. If it be under-done, its 
virtues will not be imparted, and, in use, it will load and oppress the stomach, if it be over-done, it will yield a flat, burnt, and bitter taste, its virtues will be destroyed, and, in use, it will heat the body, and act as an astringent."-(Moseley, p. 39.)

Regulations with respect to Sale, Importation, \&c.-Roasted beans and rye, reduced to powder, have frequently been used to adulterate ground coffee: and the possession of such substitutes for coffee was formerly an offence punishable by the forfeiture of the articles, and a penalty of $100 l$. But by the act 3 Greo. 4. c. 53., persons who are not dealers in coffee may take a license for roasting and selling corn, peas, beans, or parsneps, labelling the parcels with the names, and conforming to the various regulations prescribed in the act.

Dealers in coffee must take out a license, renewable annually, which, at present, costs 1 ls.

No coffee can be imported in packages of less than $100 \mathrm{lbs}$. nett weight.

No abatement of duties is made on account of any damage coffee may have received. Coffee cannot be entered as being the produce of any British possession in America or of the Mauritius, until the master of the ship in which the coffee is imported deliver to the collector or comptroller a certificate of its origin, and declare that the coffee is the produce of such place(8\& 9 Vict. cap. $86, \S 38$. 


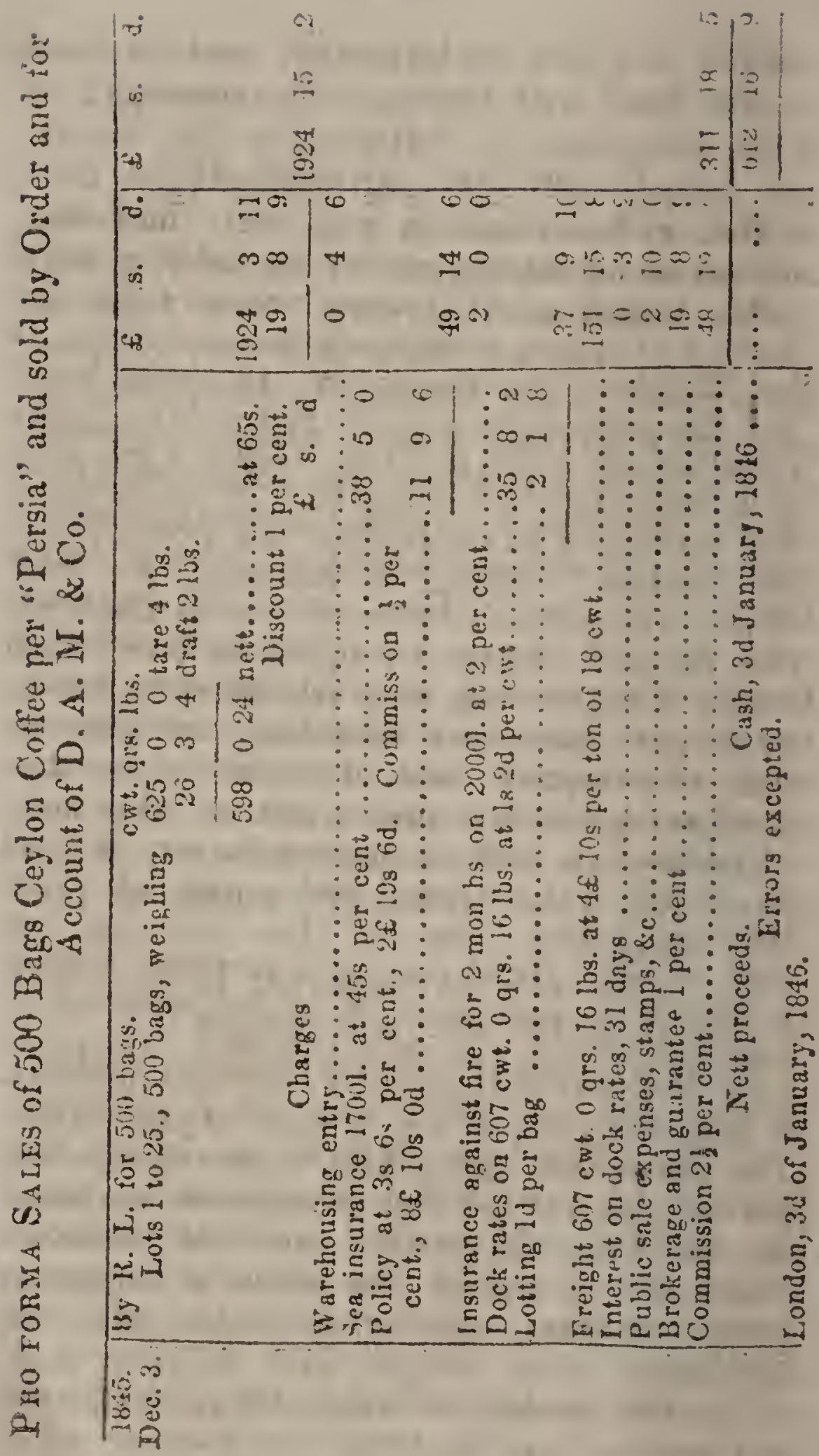




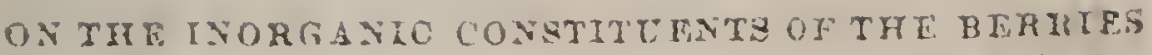
OF THW COFFRK YIANT (OOFFRA AMABCA.)

\section{By Thornton J. Herapath, Esq.}

Having been desirous, some short time since, of determining the best manure for the West Indian coffee plantations it became necessary for me, in the first place, to ascertain the composition of the inorganic constituents of the coffee berry. For this purpose $150 \mathrm{grs}$. of very fine West Indian coffee berries, which had been dried in a gas stove at a temperature of about 220 . F., were taken, and carbonized at a gentle heat in a loosely-covered platinum crucible, recommended by Prof. Rose. The carbonaceous mass thus obtained was then repeatedly digested with boiling water, until a drop of the solution, when evaporated to dryness on a glass plato over a spirit-lamp, left only the slightest perceptible trace of residue; it was then dried and heated to redness in a large fat-bottorned platina dish, over an Argand burner, until all the carbon was consumed and a pure white ash remoined behind. The ash thus obtained was very carefully transferred to a porcelain crucible containing a small lump of neutral carbonate of ammonia, and it was then subjected to a gentle heat, the top of the crucible having been previously imperfectly closed with a piece of plantina foil. The soluble salts having been extracted from the ash by means of hot water, the solution was added to that from the charred mass, and the whole evaporated to dryness; the weight of the residue which comprised the entire soluble salts was 2.01 grs.

The salts insoluble in water, having been dried and heated to dull redness, were found to weigh 
2.94 grs. ; which, when added to the weight of the ash.

The process of analysis pursued in this investigation was similar to the one described by me in a paper "On the composition and distribution of the inorganic substances in the different organs and component organic parts of the mulberrytree," recently communicated to the Chemical Society.

The soluble salts were found to contain-

Phosphoric acid ......... 0.904

Sulphuric acid $\ldots \ldots \ldots \ldots 0.011$

Potash ................ 0.755

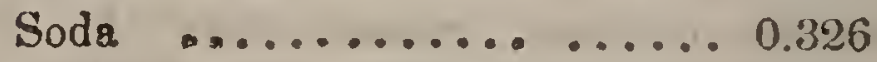

Clorine ............ 0.018

2.014

-excess of oxygen in soda 0.004

2.010

The insoluble salts contained-

Carbonic acid .......... 0.381

Sulphuric acid ......... 0.047

Phosphoric acid ......... 0.960

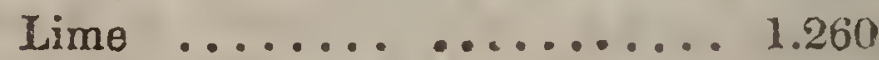

Magnesia ........... 0.272

Silicic acid $\ldots \ldots \ldots \ldots .0 .020$

2.940

4.950

* Some error which we have not the ineans of rectifying. It stands so in the Ceylon Times, from which Paper we have reprinted the article. En, C. O. 
From these analyses it follows that the per centage of ash is 3.3 , and that 100 grs. of the ash contain of-

Phosphoric acid ....... $1827 \%$

Sulphuric acid ........ 0.224:

Potrsh $\ldots \ldots \ldots \ldots \ldots \ldots$. 15.238

Soda .............. 6.26

Chloride of sodium ....... 0.606

Carbonate of lime ...... 3.8.38

Carbonate of maguesia .... 11.515

Sulphate of lime ........ 1.616

Phosphate of lime (tribasic). . 40.022

Silicic acid .......... 0.404

100.000

Deducting the carbonic acid, we obtain the following per centage composition:-

Phosphoric acid ........ 19.801

Sulphuric acid $\ldots \ldots \ldots \ldots, 0.244$

Potash .............. 16.515

Soda ............... 6.787

Chloride of sodium ...... 0.645

I lime . . . . . . . . . . . 2. 2.329

Magnesir ............ 5.942

Sulphate of lime ........ 1.751

Phosphate of lime ....... 45.551

Silicic ach .......... 0.438 
And, conseçuently, for every ton of dried coffee herries that is raised on a plantation, the proprieor sunst consider about the tollowirg quantities of the various mineral substances as having been removed from his land:-

liss. oz.

Phosphoric scid ....... $27 \quad 14 \frac{1}{2}$

Suiphuric acid ........ 0 o $13 \frac{1}{2}$

Potash ............. I1 4

Soda ............. \& 10

Chloride of sodium, or com-

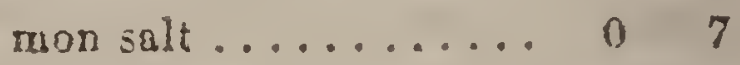

limo ............ $18 \quad 14$

Magnesia ........... 4 (

Silicic acid, or silica ..... 0 5

685

Chemical Gazctie. 



\section{LIBRARY OF CONGRESS}

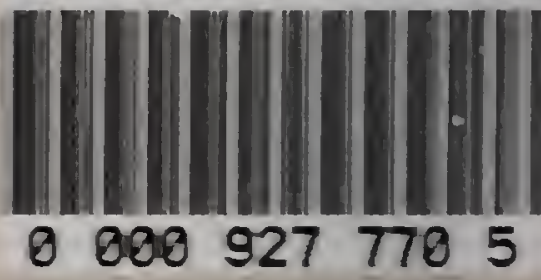

